Chapman University

Chapman University Digital Commons

Fall 12-2021

\title{
Kagame's Ruse in Rwanda: The Debilitating Role of Authoritarianism in Rwanda and its Impact on Long Term, Sustainable Development
}

Manuel Grajeda

Chapman University, mannyg969@gmail.com

Follow this and additional works at: https://digitalcommons.chapman.edu/international_studies_theses

Part of the African Languages and Societies Commons, and the Race, Ethnicity and Post-Colonial Studies Commons

\section{Recommended Citation}

Grajeda, M. (2021). Kagame's ruse in Rwanda: The debilitating role of authoritarianism in Rwanda and its impact on long term, sustainable development [Master's thesis, Chapman University]. Chapman University Digital Commons. https://doi.org/10.36837/chapman.000322

This Thesis is brought to you for free and open access by the Dissertations and Theses at Chapman University Digital Commons. It has been accepted for inclusion in International Studies (MA) Theses by an authorized administrator of Chapman University Digital Commons. For more information, please contact laughtin@chapman.edu. 
Kagame's Ruse in Rwanda: The Debilitating Role of Authoritarianism in Rwanda and its Impact on Long Term, Sustainable Development.

\author{
A Thesis by \\ Manuel M. Grajeda \\ Chapman University \\ Orange, $\mathbf{C A}$ \\ Wilkinson College of Arts, Humanities, and Social Sciences \\ Submitted in partial fulfillment of the requirements for the degree of \\ Master of Arts in International Studies
}

December, 2021

Committee in Charge:

Andrea Molle, Ph.D., Chair.

Lynn Horton, Ph.D.

Victoria Carty, Ph.D. 
The Thesis of Manuel Grajeda is approved.

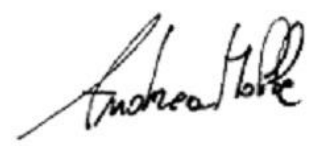

Chair. Andrea Molle, Ph.D

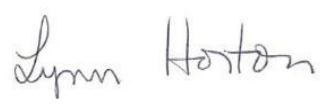

Lynn Horton, Ph.D

c. Ade cong

Victoria Carty, Ph. D

November, 2021 
Kagame's Ruse in Rwanda: The Debilitating Role of Authoritarianism in Rwanda and its Impact on Long Term, Sustainable Development.

\section{Copyright $(\mathcal{2 0 2 1}$}

by Manuel Grajeda 


\begin{abstract}
Kagame's Ruse in Rwanda: The debilitating role of Authoritarianism in Rwanda and its impact on long term, sustainable development.

by Manuel Grajeda
\end{abstract}

Following the genocide in 1994, Rwanda has been touted as a major, international development success, gaining praise and attention from the international community who place the prosperity of the nation in the hands of Paul Kagame, the leader of the Rwandan Patriotic Front and the country's current president. Indeed, under the leadership of Kagame the country was able to get through the horrors of mass killings and nationwide destruction and it is true that the country has made a serious turn around in the past 25 years. However, while the country is acclaimed to be a model for developed democracy in the Global South, my research, amongst a plethora of other scholars, has found that the nation is far from, rather portraying a gilded appeal of democracy while a more authoritarian leadership rules over the country. At the initial start of this research, the goal was to analyze how Kagame's authoritarianism had so much success developing a nation with little to no democratic freedoms in place, but as the research continued it was discovered that the "development" of the nation is more of a ruse and the nation's economic and political advancement is dependent solely on maintaining an iron grip on people's view of the country, information and freedom of speech and thought. Internationally, the nation is heavily funded and dependent on foreign aid, which is funneled to a select oligarchy in the country. Political diversity is, overall, nonexistent and leadership has been accused of manipulating economic statistics to continue the ruse of development. In this work, I aim 
to show how the lack of democratic freedoms and the brutal enforcement of authoritarian measures has led to little economic gain in the country, false political inclusivity and diversity, and left the country with essentially the same ethnically controlled system as was before the genocide in 1994. While in the short term, little development has occurred, I argue that in the long term, due to the current operation of the country under Kagame and his iron fisted leadership, sustainable development cannot occur. 


\section{TABLE OF CONTENTS}

$\begin{array}{ll}\text { Introduction } & 1\end{array}$

$\begin{array}{ll}\text { Research Design and Methodology } & 3\end{array}$

$\begin{array}{ll}\text { Literature Review } & 7\end{array}$

$\begin{array}{ll}\text { The Connection of Democracy and Freedom } & 9\end{array}$

Colonial History of Rwanda $\quad 11$

$\begin{array}{ll}\text { International Guilt } & 16\end{array}$

$\begin{array}{lr}\text { Theory of Benevolence } & \mathbf{2 0}\end{array}$

$\begin{array}{ll}\text { Paul Kagame's Rwanda- a Ruse Democracy } & 25\end{array}$

Indoctrination- Ingando: $\quad 33$

Indoctrination 2.0- The Gacaca Court System 4

Deviating from the Story: Disappearances, press suppression and international $\begin{array}{ll}\text { condemnation. } & 46\end{array}$

Borrowing, aid, reports, development and sustainability: $\quad 52$

$\begin{array}{lr}\text { Concluding Remarks } & 58\end{array}$

1. The Short Term $\quad \mathbf{5 9}$

2. The Long Term $\quad \mathbf{6 0}$

3. Sustainable Development: the necessity of democratic freedoms for economic and political success. $\quad \mathbf{6 2}$

$\begin{array}{ll}\text { Appendix } & 65\end{array}$

$\begin{array}{ll}\text { References } & \mathbf{7 0}\end{array}$ 


\section{Introduction:}

From April to July, 1994 one of the worst modern human catastrophes laid waste to the Rwandan countryside. After four months of internal strife, one million ethnic Tutsis, Rwanda's minority ethnic group, lay dead, victims of an ethnic cleansing campaign committed by the radicalized Hutu population. During these three horrific months, the Rwandan Patriotic Front (RPF), led by the now president, Paul Kagame, pushed back against the extremists and eventually brought the country out of the conflict and into an era of sustained peace, a peace which is still apparent to this day. In fact, the country's “economy appears to be thriving, with annual GDP growth averaging 7.76 percent between 2000 and 2019” (Keffler, 2019), being labeled by international leaders and UNESCO as an economic miracle. Even during the pandemic, where much of Rwanda's economic growth was lost, the country is said to pick up speed in 2022 with growth exceeding what it has already produced. Today, most "commentators attribute Rwanda's resurgence to the visionary leadership of one man” (Taiwo, 2018), Paul Kagame. Under his leadership the country has opened up much of Rwanda's free market, pushed for women's rights, developed social welfare programs and transformed the nation culturally in many ways. Touted by Bill Clinton as one of the greatest leaders of our time and a visionary by Tony Blair, it truly seems under Paul Kagame's leadership the country is worth noting as an outstanding example of developmental success in the Global South.

However, it is also under this same leadership that Rwanda has suffered, but in a way that is not measured in the same, but yet deemed imperative, if not mandatory for successful and sustainable development. Kagame has been accused of several human rights abuses, voter suppression and even, in extreme cases, ousting political competition to remain in power. Regarding the economic success of the nation, many journalists have reported that "more than 
14,000 data points and interviews with academics shows that rising prices for Rwandan families meant poverty most likely increased between 2010 and 2014" (Germain, 2019). Reports from 2015 onward have also shown multiple attempts to misrepresent the data regarding poverty, statistics not well covered in GDP reports surrounding the nation.

Many of his critics argue that he rules "as a benevolent dictator, who pursues unselfish goals for the development of the country" (Cascais, 2020). As unselfish as his efforts may be, under Kagame's leadership, the country has changed the constitution, allowing him to run for an unprecedented third term in 2017, which will allow him to stay in power until 2034. While Kagame's success in rebuilding the nation after the genocide was a valliant and critical part of the country's "economic miracle" story, it also begs the question about how to properly define 'sustainable development' when it comes to the reconstructing of global south countries following a social rupture like the 1994 genocide. Additionally, I will analyze how Kagame rebuilt and united the county and the sustainability and legitimacy of that foundation- a foundation which many scholars have called into question over the last two decades.

In the United Nations General Assembly 51/240, under article 26, the agenda for development reads "democracy, respect for all human rights and fundamental freedoms, including the right to development, transparent and accountable governance and administration in all sectors of society, and effective participation by civil society are also an essential part of the necessary foundations for the realization of social and people-centred sustainable development" (Anonymous, 1997). Furthermore, countless political and economic thinkers attribute democratic reform as imperative to sustainable development success, yet we find Rwanda, a country led by an iron fisted ruler, being praised by western, democratic leaders as a economic, developmental success story- how can this be? 
It should be stated that the goal of this paper is not to diminish the value of democracy, democratic participation and activity in governments across the world. Rather, this work simply examines the question of whether or not successful and sustainable development can occur without democratic institutions in place. Using Rwanda as a case study, this paper argues that development, which has been touted by western leaders across the globe, has indeed occurred in this situation, but is perhaps not as clear and clean as it is liked to be imagined. Rwanda's development has been stifled in many ways by its political system and while its development miracle could lead us to "question whether the Eurocentric obsession with democracy is of any benefit to developing African nations" (Taiwo, 2018), it is also important to understand the limitations that it brings to creating sustainable development in a country riddled with political discontent. Thus, our paper is an examination of democracy and the lack thereof within the developing nation of Rwanda and question its sustainability and legitimate development under Paul Kagame and his authoritarian rule.

\section{Research Design and Methodology:}

This research is based primarily on secondary research, consisting of scholarly works on the issues of corruption within the Rwandan government (RPF) as well as the social indoctrination within the country today. Journals, news reports, other academic thesis' and economic databases are used throughout this work to provide a clear and concise view of how the Rwandan government has operated over the years after the 1994 genocide, as well as the economic impact of the policies thereof. This research begins with a discussion on the connection between democracy and freedom, articulating how freedom in civil society is to be 
defined. Furthermore, much of Amartya Sen's work on freedom within societies and its connection to sustainable development is imperative and necessary to the work, providing a base on how this thesis analyzes and views civil society, the freedoms they hold within Rwanda and how the violations of those freedoms have created a system where I question the long term sustainability for development. The work continues by giving a brief overview of the colonial history of Rwanda and the breakdown of how society was organized prior to the 1994 genocide. Ultimately, the colonial separation of ethnic groups (Hutu, Tutsi and Twa) gave way to the horrors seen in 1994, which later gave rise to the central figure of this thesis, Paul Kagame. Moving into our discussion on Paul Kagame and his iron grip on the country, using interviews conducted by other scholars in Rwanda, academic works on authoritarian development, and eye witness accounts to policies implemented in the country, I analyze how Kagame's rule, while on the surface seems like a prosperous and democratic developing nation, is actually a ruse which both politically and economically is not sustainable in the long run. Using reports found in recent database materials from the International Monetary Fund, United Nations and World Bank, Rwanda from a development view demonstrates a strong dependence on economic aid, which forces us to question how legitimate the economic success of this “development darling” actually is. From a political point of view, I analyze published interviews with former politicians and citizens in the country who were not a part of the ruling party, or defected away from it, to show how the political fabric within the country is thin and unstable, especially with the development of social media where many people opposed to the rule have been able to, within the last decade, post their thoughts. Of course as will be analyzed throughout this work the repercussions for going against the monolith ideology of the RPF and ultimately Kagame, have resulted in disappearances, extended jail times, exiles and, in the worst cases, 
murders. Thus, with repercussions like this, fear seems to be the major hold over the people, which I argue, in the long term development, goes against democratic reforms and is not sustainable in the long run. Especially because Paul Kagame has maintained, and will continue to maintain, central authority over the country for over thirty years. It also seems that there is no one in the plans to replace or follow his leadership, which also begs the question of political sustainability in the country after he is gone.

Comparatively, this has been seen historically. After the death of Mao Zedong, a notable authoritarian leader, the Communist party of China flailed to find leadership and the economy stagnated for almost a decade. In the post Joseph Stalin world of the Soviet Union, the country had to go through a period of de-Stalinization, cleansing the country of its horrors committed under the totalitarian ruler, arguably never truly reaching a freely expressive state until the collapse of the country in the early 1990's. In Uganda, just north of Rwanda, following the ousting of General Idi Amin Dada of Uganda, the country's inflation rose to 1000 , which the country is still reeling from in many ways to this day. While for the sake of this research, it is difficult to compare a small, landlocked country like Rwanda to megalithic countries like China and the former USSR, the point here is to note that authoritarian leadership throws away the process of political transition and, thus, leaves political and economic uncertainty for the future. For a small country that is highly dependent on foreign aid, it leaves us questioning what happens after Kagame's authoritarian years are over?

There is a plethora of literature regarding autocratic rule and the benevolence thereof, which is used throughout this thesis. It is important to analyze how autocrats deemed benevolent rule over their nations and the successes that can come with that. This paper strives to view those successes and examine their legitimacy within the framework of sustainable development. While 
there is research that suggests "some autocratic regimes have fundamentally transformed their economies, despite serious deficiencies along a range of other dimensions" (Gilson \& Milhaupt, 2011), I raise the concern that those other dimensions, such as extreme violations of civil liberties, political rights and transparency are imperative to the long term and successful development of these nations, using Rwanda as our case study. In particular, I will be examining the strategies used by the RPF in the aftermath of the genocide, and how those policies have aimed to control the way many Rwandans view their history and their role in the country today. Using eye witnesses, published accounts of those who have gone through the social indoctrination processes known as ingando camps and judicial process of the Gacaca court system, both of which are controlled by RPF officials, I will examine how the tight control over the narrative has been imperative to maintaining dominance over the political infrastructure in Rwanda. Testimonials from political leaders published and documented in journals and reports from organizations such as Human Rights Watch as well as government supporting news outlets such as The New Times, will decisively acknowledge and support the fact that the aims of the country's leadership are more towards an obedient way of thinking that is dictated by the RPF and Kagame, creating an atmosphere of political, civil and social repression that is highly guarded and secured by the national government. Using these sources and published accounts and reports of political and social repression, I demonstrate that Rwanda, while perhaps from the outside looks like a democratic, developing state, is in fact an autocratic regime ruled by tyrannical practices, which while having some successes in maintaining peace and security in the country in the short run, in the long term, could be devastating as the foundation is supported by violent rhetoric and practices and an economy dependent on international funding and manipulated statistics. 


\section{Literature Review:}

In this next chapter I will be examining the literature and supporting research behind our question regarding whether democracy is needed in sustainable development. In our first section I will examine the connection between democracy and freedom, exploring much of Amartya Sen's work on the two and how imperative they are for successful, sustainable development in the long term. Following that, I will examine the role the international community plays in regard to Rwanda's development, analyzing how a nation with an autocratic, oppressive leader seems to go unchallenged in the international political sphere. On the contrary, Rwanda is deemed an international development economic miracle by many democratic leaders throughout the world. Using Filip Reyntjens work on Rwanda and Paul Kagame’s political history, I examine how an international guilt syndrome dominates the political affairs between Rwanda and other democratic countries due to the lack of response from the international community during the 1994 genocide. In this section, I examine how, due to this event, the international community tends to ignore the suppression of civil, social and political rights in the country, arguing more that the rapid economic success of the nation, which I will call into question, and not the democratic and civil development, right after the genocide is attributed to the leadership of Kagame despite the well documented claims of abuse, jail time and murder.

Later I also examine how international funding is part of the problem that keeps Rwanda under the oppressive rule of Kagame, noting that the high percentage of international aid pours directly into the RPF's campaign projects while making it illegal for those outside the political party- in other words, aid is monopolized and used to maintain oppressive social tactics, such as 
controlling news outlets and free speech; thus, manipulating the way outsiders view the country's democratic freedom development. While some of these projects are for the development of the country, they also help to support campaign maneuvers, which have helped create economic barriers for dissident political parties and suppress free speech, press and information throughout the country.

In our last few sections I examine the literature regarding the social engineering programs and judicial processes used in Rwanda to maintain a common narrative that is not to be deviated from by the country's citizens. I note the process of justice (Gacaca) used post the genocide created an uneasy system of justice and the Ingando camps portray a vision of the RPF and Kagame as savior like beings, creating a country ruled by a cult of personality that when gone, is unsustainable in the long term for development. Additionally, our research acknowledges that with the development of social media platforms such as YouTube, Instagram TikTok and Facebook, more of the citizenry of the country, and those outside as well, are speaking out against the regime, which has resulted in kidnappings, disappearances, murder and, in some extreme examples, cases of violations of international law. These sections highlight arguments made by Amartya Sen, Filip Reyntjens and Hilary Matfess to name a few, that while authoritarianism can have rapid economic growth, the sacrifice of democratic freedoms creates instability, which I argue throughout this work goes against the ideas of sustainable development. The research used for this consists of academic thesis, journals, international and domestic newspapers as well interviews conducted by many scholars with local Rwandese. 


\section{The connection of democracy and freedom:}

Understanding democracy's connection to freedom and freedom's connection to democracy can be a confusing, lexiconic conversation due to the fact that when it comes to development there are a series of different theories and definitions that it abides by. For some, more so in the economics field, "a basic precondition of development is a minimum legal and contractual structure and a set of well-defined and enforced property rights; the general presumption in this literature is that democracy is better-suited in providing this environment (Bardhan, 1999). For other theories in development, "freedom means individuals may choose how to interact on a voluntary basis outside the purview of the state" (Wenders, 1990). For Nobel Prize Winner, Amartya Sen, attention must be paid to the "expansion of the 'capabilities' of persons to lead the kind of lives they value- and have reason to value" (Sen, 1999). Within these definitions lies a common ground of freedoms and the capability to act out these freedoms. But when discussing freedoms what exactly does that mean? Within this work I examine freedoms from a Senian approach, analyzing how members of a society (in our case study, the Rwandese) are able to interact within the political and social atmosphere. With this, meaning how free are people to vote as they please and is information available to the people without oppressive violence to coerce a certain way of thinking? Are people able to freely speak their opinion without fear of oppression and retaliation? Does the political infrastructure create a place for free thinking or does it aim to manipulate the masses through controlled media and indoctrinization practices? Thus, "the success of a society is to be evaluated, in this view, primarily by the substantive freedoms that the members of that society enjoy" (Sen, 1999). 
Within the field of international development, Amartya Sen's approach seems to have dominated international institutional thinking as well as Global North nations involved in sustainable development, as seen in UN Assembly 51/240, in the Global South. Many of these points align almost verbatim with Sen's essential freedoms ranging from government transparency, collective civil societal involvement in governance and the simple freedom to think how one chooses to think without government repression. Thus, how a citizen participates, interacts and enjoys these freedoms, perhaps, is a simple way of explaining the connection between freedom and democracy as democracies untether (free) citizens from more authoritarian aspects of governance in development, where they may be coaxed, indoctrinated or pressured into a certain way of thinking. Citizens who are able to live in societies where their government allows for the freedom of political diversity and security, press, speech and governing transparency creates the free citizen that Sen is referring to. A government that represents the whole and the diversity thereof also must share the values of these freedoms as citizens who enjoy these freedoms must be allowed to express them within their political governance. One goes hand in hand with the other and, as Sen argues, is imperative to sustainable development. Within the case of Rwanda I will analyze and measure these freedoms and how these freedoms or lack thereof play a role in the sustainability of the country, both economically and politically. I will also analyze how Rwanda is portrayed by many in the international community as a development darling due to its quick reforms that took place immediately after the genocide. However, our examination will look much closer at the political institutions and infrastructure in the country to see whether or not the freedoms articulated by Sen and other scholars for sustainable development hold up and can be sustained through Rwanda's iron fisted, "benevolent" authoritarian state. 


\section{Colonial History of Rwanda:}

Rwanda is a small, landlocked nation located in central Africa with a colonial history stretching back to the early 20th century. Prior to the emergence of imperial rule in central Africa, Rwanda was divided into primarily two ethnic groups: The Hutu and the Tutsi and of which the former tended to be farmers and the latter cattle herders. The system, known as Ubuhake, defined "a social system in which the Hutus worked in the service of Tutsis in exchange for cattle" (Skok, 2020). As this system was normalized, so too did it characterize the relationship between the two ethnic groups. In 1899, when the Germans arrived in the country, Rwanda was, for a short time, a colony of the East African section of the German empire and it was during this time that the subjugation of the Rwandese, specifically the Hutu, began and ethnic segregation, placing the Tutsis in a socio-economically superior position based on their biological identity being closer to caucasian and, thus, making them more fit to rule the country, or so the theory went.

However, after the defeat of the Germans in World War I, the colony was passed onto the Belgians and absorbed into their empire as a mandate under the League of Nations. While the colony passed back and forth between two empires of the time, it was under the rule of the Belgians that Rwanda's colonial-ethnic segregation truly began. Under the Belgians the "most lasting effect was how the colonial authorities racialised the differences between Hutu, Twa and Tutsi" (Anonymous, 2016). Under the Belgian government, ethnic identities became cemented in society, a radical change as prior they were more "fluid identities which people moved in and out of depending on the work they did and their status in society. The colonial government made 
them permanent markers, people were either Hutu or Tutsi and you were born into one or the other" (Anonymous, 2021). Throughout the 1920's and 1930's these ethnic identities were institutionalized at the federal level in Rwanda, mandating that all Hutus were to be ruled by Tutsis and, furthermore, "through changes in the legal system and mandatory identity cards to specify whether people were Hutu or Tutsi, the Belgians had constructed the Hutu and Tutsi as two distinct races" (Anonymous, 2021).

In the post World War II years, and after the worst famine in the country's history (1941-45), colonial leaders started changing some older institutionalized systems in place, for example getting rid of the Ubahake system and granting Hutus, whom had developed an elite class, more rights in society. Much of this was due to pressure put on authorities from the United Nations, which the country had become a mandate of in the post war years. Local councils began to hold elections, however, much of these higher level positions were dominated by Tutsi leadership (a theme that will come up later in our discussion of Kagame's ruling party leadership) and tended to move towards a form of subjugation of the Hutu majority. In 1956, national elections finally came to be, but "because representatives were elected indirectly by an electoral college made up of mainly Tutsi chiefs, the result was in favour of Tutsi representatives" (Anonymous, 2021), thus, creating a new future of Rwandan leadership dominated by the minority opinion of Tutsi officials. In the latter years of the 1950's, Rwandans began demanding independence from Belgium, but with this new system of government where Tutsis held almost all political power (Hutus during this period only controlled roughly $6 \%$ of representative positions) it became very clear that "all the reforms were limited in scope or in implementation and at the end of the day would never be enough to give Hutu people equal rights in Rwanda" (Anonymous, 2021). 


\section{Decolonization and the Rise of Paul Kagame:}

In the late 1950's going into the 1960's, Rwandan political parties began to form around the ideas of independence and how the country should be ruled in a post-colonial era. Much of the tensions between the political parties rested, not in colonial/colonized oppression, but in the ethnic differences between Hutus and Tutsis, where as leading, aristocratic Tutsi officials believed the country should return to its roots which included the system in which Tutsi ruled over Hutu. It should be noted that multiple political parties formed during this period such as “two main Tutsi aligned parties UNAR (traditionalist and monarchist) and RADER (soft-reformist), and the two main Hutu aligned parties were PARMEHUTU (revolutionary and eventually anti-monarchist) and APROSOMA (started out as a populist party for both Hutu and Tutsi, and became the moderates)" (Anonymous, 2021). Rwanda's post-colonial history, while very different from the country's contemporary political system, is not unfamiliar to a multiple

political party system in which political ideologies sharply contrasted with each other. However, it should be understood that the differences in ideologies led to violent clashes between the groups, resulting in escalating hostilities all the way up to the genocide in 1994.

By the 1960's, the Hutu party PARMEHUTU gained significant political power and established the First Rwandan Republic, which led to the ousting of the monarchy, a Tutsi exodus and a rise in Hutu dominance within the socio-political infrastructure within the country. However, in 1973, as socio-economic conditions collapsed within the country due to unemployment and little opportunity, Major General Juvénal Habyarimana seized power in a military coup to 'quell the unrest' within the country, forming what would be known as the 
Second Rwandan Republic. While Rwanda during the early post-colonial years created a diverse political system, the system itself was not sustainable due to the violent dividing factors established under colonial rule between Hutus and Tutsis. Perhaps a foundational step, which would later be instituted in many ways by Paul Kagame upon his ascension to power, Habyarimana created the new political party, the Révolutionnaire pour le Développement, which all Rwandans were forced to be part of. Refugees, located in Nairobi, Kenya, simultaneously formed the Rwandan Patriotic Front (RPF). However, within Rwanda, all other political parties were outlawed and elections generated an astounding turnout with $98 \%$ of the vote going to President Habyarimana (a similar theme we will see in Kagame's elections post 2000). Of course, these elections can and should be labeled as rigged, but they gave the appearance that the developing nation was in line with democratic tendencies, a notion that I will examine more as Paul Kagame's current regime demonstrates similar patterns of this style of authoritarianism.

It is in the 1980's that we see the rise of Paul Kagame as a key and central figure within the Rwandan discourse. By 1987, Kagame was Chief of Military Intelligence in Uganda (where Rwandan refugees were) and helped the National Resistance Movement plan an invasion into Rwanda in the following years. Kagame, who had returned from military training in the United States, helped in the planning of this invasion, which won several victories in the early 90's, but failed to turn these into long term, strategic holds on the countries hostilities. Much of this was due to the fact that the country was dominated by Hutu farmers who saw the RPF as rebels and would flee upon their arrival. It was during this time that over 950,000 Hutu were internally displaced around the country. It became clear upon the invasion there would be an "end to the attempts of reconciliation which the regime of President Habyarimana had begun" (Anonymous, 2021). Instead of politics focusing on national unification, it would be one focused on Hutu 
power and by 1992 the youth militia groups started to form around the country, the most famous known as the Interahamwe. As these groups grew to prominence, violence and massacres were committed against the Tutsis within the country and "both the Interahamwe and the Rwandan government army were supplied with weapons and materials by the French.” (Mamdani, 2002). In turn, and using these internationally supplied arms, to "strengthen the government's war effort, President Habyarimana began arming the civilian population" (Mamdani, 2002). These groups would be central in the civilian militias who would carry out the attrocities committed during the genocide in 1994. Adding fuel to the fire, a peace treaty, signed in Arusha, Tanzania between the Rwandan government and the RPF, was rejected by the president due to it excluding proponents of Hutu power from the political order. After this, the Rwandan Prime Minister "was killed together with the ten UN soldiers guarding her, the UN (with the USA in charge) decided to pull out all but 270 of the UN soldiers stationed in the country" (Mamdani, 2002). With tensions high, the spark was on April 4th, 1994 when the president's plane was shot down and his then prime minister, Agathe Uwilingiyimana, confirming Hutu suspicions that a Tutsi take over of Rwanda was iminents and, thus, the genocide ensued. On July 4th, three months after the genocide began, Kigali was captured by the RPF and a new government was installed with Paul Kagame as the de facto leader. During this time it is estimated that over two million Hutu fled the country, mainly to The Democratic Republic of the Congo, a location of another conflict that would ensue in what is to be known as a revenge genocide under the reign of Kagame in the following years.

Since this time, Kagame has held central and almost unquestioned power within the country, using this historical moment to develop a sort of cult of personality, which dominates the everyday socio-political infrastructure of the country. Much of the contemporary criticisms of 
Kagame's dictatorial hold on Rwandan authority are brushed away due to the historical narrative that was generated after the war. Admittedly, the international community failed to act in a manner that was morally and ethically needed at the time. The French supplying of weaponry to Habyarimana's government and violent militia groups would and still does play a huge part in Kagame's justification for power in modern Rwandan. Additionally, the UN troop pull-out and international denial of the genocide left Kagame with an extrodinary ability to illustrate a narrative with him as the unquestioned liberator and hero of Rwanda, single handely leading the country to a better future; thus, the interrnatioal guilt narrative as discussed by Filip Reynjentes was created. This is the narrative which plays a major role in the question being asked regarding the sustainability under Kagame's modern authoritarian hold on the country and whether or not a developing nation like Rwanda can sustain itself in a post-Kagame status- in other words, the long run.

\section{International Guilt:}

Throughout the genocide western nations took a step back, France even going as far as withdrawing its own citizens from the country to avoid them being caught up in the violence. The United States, among other Global North leaders, played ignorant to the carnage, stating they "did not fully appreciate the depth and the speed with which [Rwandans] were being engulfed by this unimaginable terror" (Robinson, 2016). For the United States, being, for the first time in over five decades, in a post-Cold War world, meant the intervention around the world had to be strategic and much of it had to do with the "spread of democracy in the eastern bloc and other erstwhile communist nations" (Giridharadas, 2018). While the U.S. had and was playing a 
role in Africa, after the failure in Somalia, the U.S. "had no interests in Rwanda, a small central African country with no minerals or strategic value" (Carol, 2004). Thus, as seen, Rwanda and its leadership, Paul Kagame and the RPF, were left alone to handle the genocide and reconstruct the country afterwards, shaping the way to Kagame's iron grip on the country, which has been reinforced by western leaders, due to their lack of itervention, ever since.

As the genocide came to an end in July, 1994, much of the western world realized that its lack of action during the genocide arguably contributed to its continuation. As President Clinton stated "as our fragmentary awareness of crimes grew into indisputable facts, far too little was done" (Robinson, 2016), and indeed this was probably true. Intervention from western powers would have indeed, potentially, had an impact on the longevity of the genocide, but because of this inaction, the relationship between Rwanda and the west today, especially given the honorary title Rwanda holds as the 'economic miracle of Africa,' is one which far too often ignores the true actions used by the RPF and Kagame to maintain stability and development in the country. Kagame's government often waivers between "political openness and inclusivity and on the other hand a violent mode of management and discriminatory practices" (Renjentes, 2004). In foreign policy, massive amounts of fleeing Hutus, who left the country during the genocide to seek shelter in The Democratic Republic of the Congo (mainly children, elderly and the sick) were ruthlessly extinguished in the 1996 invasion of the country as part of a revenge campaign for the Tutsi extermination in Rwanda. Many experts label this as Africa's World War and as of now the number of casualties hovers around six million. I will discuss this conflict and how it alligns with Kagame's style of governing in further detail later in this work, but in the aftermath “The International Center for Human Rights and Democratic Development (CIDPDD), in teaming with the African Association for the Defense of Human Rights in DRC (ASADHO), 
concluded that 'it appears pertinently that the Rwandan government can be held accountable for war crimes, crimes against humanity, and acts of genocide"' (Anonymous, 2018), crimes Kagame and his RPF fought to end in 1994 and which ultimately brought him to power.

Still, within this framework, and the 'democratic leadership' possessed in the country, western democratic leaders still praise Kagame for his remarkable governing and economic development success. In fact, "the country has also benefited from a steep increase in foregin direct investment (FDI) since the mid-1990's, climbing from U.S. \$7,660,000 to over U.S. $\$ 110,000$ since 2004" (Matfess, 2015). With a country riddled with a history of ethnic violence and a governing party that later committed in an act of revenge genocide against the Hutus in a foreign nation (Zaire); authoritarian leadership with shadow parties that resemble democracy; and an utter lack of government and political transperency, how is it that this country still receives foreign aid to maintain its sustainable development? Furthermore, why does a country like this garner such praise from the western world for its governance? As professor Filip Reynjentes explores "the Rwandan government has succeeded in avoiding condemnation by astutely exploiting the 'genocide credit' and by skillful information management" (Reynjentes, 2004). Countries who were aware of the genocide and did little to nothing (France, UK, and U.S.) are driven "by an acute guilt syndrome after the genocide, they reasoned in terms of 'good guys' and 'bad guys', the RPF naturally being the 'good guys"' (Reyjentes, 2004). Thus, in many ways, the international democratic community contributes to this continuation of quasi-authoritarian rulership in the country due to a guilt syndrome that dates back to the post genocide years. The fact that Rwanda is able to show on paper in economic and measurable terms that it is growing, although this statistics are highly questioned, and perhaps has a facade of a democratic government, allows western nations to feel good about their contribution and 
point to the nation as a developing success. However, while the economic achievements of the country are perhaps significant and exemplary, this does not mean that democratic and political freedoms are enjoyed in this country and does not demonstrate that this could maintain long term success.

On the contrary, it would seem that much of Kagame's iron fisted rule is responsible for much of the rapid short term success that we see today; thus, this leads us to question, since such a successful authoritarian nation has emerged with western praise: is democracy actually part of the equation for successful, sustainable development? Kagame himself in a February, 2021 interview stated "the west does not define democracy in Africa" (Kagame, 2021). Perhaps, when examining development, the one size fits all, European centered ideas of democratization within other continental countries are displaying an irrelevance when it comes to cases such as Africa. Still, it should be asked, perhaps, if this is the kind of development that can be sustained? What happens after Kagame finally leaves office? Democratic institutions allow for change to be normalized and under an authoritarian rule this leaves a huge question for the country's sustainability. While Kagame's authoritarian rule has led to massive economic growth in the country it does not seem his political nature has followed the same path, leaving us to question whether or not this economic miracle country has the capacity to follow or enhance the same footsteps in a post-Kagame Rwanda. 


\section{The Theory of Benevolence:}

The concept of autocracies or a benevolent dictatorship is not a new phenomena and is “a perpetually popular concept in economic development discussions” (Easterly, 2011). Pinning an exact definition on a 'benevolent' dictator is tough and maneuvers through the theories of autocracies in general. William Easterly notes "benevolent autocrats assume a very simple theory where the autocrat chooses policies and then implements them. In other words, they assume an omnipotent autocrat, so that the outcomes observed under autocracy reflect the intentions of the autocrat" (Easterly, 2011). In other cases, the autocrat is part of a system of oligarchs with the main point of it being "not the absence of an electorate but a much smaller one limited to the elite, but whom still hold the autocrat accountable to their interests" (Easterly, 2011). In the case of Paul Kagame, while he works with, in parliament and other political offices, RPF members, Kagame has been known to shuffle around political positions of people within his party he deems a threat. While Easterly here notes that some autocracies can take the form of ruling oligarchs, Paul Kagame sits at the head of this table and anyone who goes against his political bidding is usually removed or, in cases I will discuss later on, jailed or worse. Thus, I would conclude that Paul Kagame rules as a one-man show- an autocrat with no one in his own political party to keep him in check.

For authors such as Sergei Guriev and Daniel Treisman, the modern autocrat maintains their authority not by the old means, of ousting political dissidents and threats of violence (which still does occur in Rwanda), but rather through a language that is more in line with the Global North- a language riddled with western notions. For Treisman and Guriev, the secret of modern autocrats lies not the terrorizing of their own citizens through imposing ideologies or isolation, 
but rather they "achieve many of the same ends by manipulating public opinion" (Guriev \& Treisman, 2019). The key is to control information, how it's interpreted to the people of that country and how the outside world views their leadership through an economic and political lens. There have been many cases where Kagame has been criticized for his role in human rights abuses, the lack of political transparency and the denial of certain freedoms, such as a free speech and open press. When criticized about this in an interview in February, 2021 Kagame simply replied "the west does not define democracy in Africa" (Kagame, 2021). This statement falls in line with Guriev and Treisman's ideology here. Kagame's response is deflective and also manipulative, allowing him to change the interpretation of democracy to apply to his way of viewing it, concluding that western ideas of democracy do not apply on the African continent, thus their criticisms hold no validity. This is mirrored again in a United Nations General Assembly meeting in 2017 when he was questioned about his speech on democracy in Rwanda following a plethora of reports regarding human rights abuses, elimination of political opponents and oppression of the press. Kagame responded in a way that aligns, yet again, with Guriev and Treisman's narrative:

It's always difficult to accuse me of anything and say prove yourself innocent...I want to turn it to you and say prove me guilty. That's where the problem lies. You know the press, human rights groups, what they say about me personally or about Rwanda...when you are in Rwanda and you are dealing with these decent human beings...also in Rwanda... and they tell you their own stories... you won't face even $.0001 \%$ of what they're talking about. The real life there is completely different than what the young girl is talking about [referencing the woman asking the question]...Rwandans are there and are no different than you, what you aspire to be, to have, to do...they are no different, but it's as if Rwandans are treated as a botanical garden, where they just water flowers. No, they are human beings like anyone else in this room. So this so-called 'human...I don't know what...' I tell you what: half of my life I've been living in the trenches, not sure if I'll live the next day....I was fighting for my rights, which no one in any 
human rights organization could give me. And even now cannot give me or cannot give Rwanda. So it's cynical and absurd that anyone would be there talking about the violations and me, as leader of my own people, violating their rights. It's just an absurd insult." (Kagame, 2017).

Within the room of this response were many delegates, reporters and members of the international assembly and institutions, most of which were praising the leader on his economic success for the country. Additionally, they seemed to agree with him regarding this, further establishing the idea that international institutions and leaders are sympathetic to Rwanda, and allow for Kagame to manipulate public opinion in spite of the amount of evidence supporting the interviewer's claim. Even in the international sphere, Kagame is able to influence and manipulate public opinion about his country by turning the question back at those who criticize him. From the international perspective, leaders and organizations seem hesitant to condemn Kagame on these issues due to what Filip Reynjentes notes as the international guilt. So, it can be concluded that Kagame holds his power using Guriev and Treisman's narrative on swaying public opinion, which is reinforced by Reynjentes notion of international guilt syndrome. Of course, Guriev and Tresiman continue, while the aforementioned methods are preferred within autocratic regimes, violence can and most certainly does occur, but rather than openly acknowledging their part in it, an old form of repression, modern autocrats tend "to conceal their involvement or camouflage its purpose" (Guriev \& Treisman, 2019). Additionally with many leaders, like Paul Kagame, who fall into this category, international funding and aid are crucial to their economic growth so much of their leadership is boasting "good economic performance and public service provision" (Guriev \& Treisman, 2019). Hence, this can, and does, generate a sort of illusion that economic success coincides with a benevolent leader and a benevolent leader must have the interest of their people at heart. This sort of thinking follows an idea where economic growth and democratic 
institutionalization are symbiotic; however, as will be seen, they most certainly are not conjoined.

There tends to be a mixing of the view that the economics of a country coincide with democracy. Since the 1980's neoliberal policies dominated the development landscape as world leaders and international organizations pushed for more open markets, which in turn gave them access and developed new market place relationships between the Global North and Global South. Of course, the subjective economic growth that came from these policies being implemented was deemed a success due to neoliberal policies being viewed as opening up more individual market freedoms for people of that developing nation. Niklas Olsen, professor of history at the University of Copenhagen, remarks in his work The Sovereign Consumer that "by making a direct parallel between choice in the marketplace and at the ballot box, neoliberals not only depicted sovereign consumers as the key drivers of capitalism and of liberal democracy, but also described the daily voting on the marketplace as the real driver of individual representation and participation in society" (Olsen, 2019); thus, the individualization that free market growth creates became directly linked to the concept of a more free and democratic society. Olsen continues by noting that "it's pretty clear that the democracy of consumers identified with the market economy often represented an analogy pertaining only to economic processes and not to a political order characterized by traditional democratic institutions and virtues (Olsen, 2019). While the economic growth that is created under these autocratic rule may be great, this is not analogous to the same construction of democratic order within the same regimes that is imperative to maintaining healthy development in the long run. 
In many ways, market freedom, and its expansion into developing nations, has become a sort of loophole for Global North democratic nations to be able to openly work with autocratic leaders by justifying benevolence through a market economic approach. So now "prioritizing the marketplace over democracy is a recurring pattern in neoliberal ideology and practice (Olsen, 2019) and creates a sort of new relationship between the democratic north and developing south: Global North leaders are able to view themselves as sort of 'market place saviors' for developing countries, which justifies their relationship between them and the autocrat. For the autocrats, they justify their rule through their economic success, which is justified by praise from the international community. In turn, this leads to more aid to flow to the nation, creating a new prerogative for developing nations: economic success trumps democratic institution building, a factor promoted by international organizations such as the United Nations and other world leaders, but seemingly ignored under the curtain or free market trade and neoliberal policies. To be clear, economic growth in Rwanda seems to equate to benevolence.

These principles of economic success go much further into the realm of economic aid as well. For western nations to support autocratic leaders openly, without implying some sort of good, would go completely against foreign policy stances of western, democratic nations so the idea of benevolence has woven itself into the fabric of humanitarian aid because "thinking of the autocrat as mostly "benevolent" (another common euphemism is "developmental") takes the focus off autocracy and puts it back on a more appealing image such as the needy populations of those nations" (Easterly, 2011). Thus, aid can flow, and has heavily increased, to these countries if their leader's policies are deemed as primarily benevolent. As long as growth continues and mild democratic forms ensue, we see that Global North nations have no problem contributing to these regimes as long as they present themselves as benevolent leaders with economic success. 
However, is Paul Kagame's Rwanda an actual economic miracle? Furthermore, what is this "democracy" that he seems to have created?

\section{Paul Kagame's Rwanda- a Ruse Democracy:}

In 2000, Paul Kagame was elected president of Rwanda and since then, the country has not seen another president in office, creating an autocratic legacy lasting over twenty years and could continue for ten plus more. From an international point of view, Kagame has become a sort of super star when it comes to development in Africa and is often attributed as the shining light of success as under his rule "economic growth has been made possible by the strength of the state and the ruling party's grip on power" (Keffler, 2019). As discussed, this super star status is often attributed to the fact that, on paper, Rwanda has seen amazing economic growth since the 1994 genocide, thriving at an "annual GDP growth averaging 7.76 percent between 2000 and 2019, and growth expected to continue at a similar pace over the next few years" (Keffler, 2019). As of now, according to the World Bank, Rwanda is expected to "reach Middle Income Country (MIC) status by 2035 and High-Income Country (HIC) status by 2050" (World Bank, 2021). Arguably, within these contexts, and within the contextual, neoliberal mixing of democracy and economics, surely democratic institutions would follow suit, yes? Unfortunately, this is where Kagame's Rwanda falls short and where the concept of sustainable development, from an institutional point of view (institutional being World Bank, International Monetary Fund and United Nations), being measured through an economic sense fails to articulate the complexities and sacrifices the Rwandese have and continue to endure in order to achieve this "economic miracle"- a miracle which I, along with many other scholars deeply question. 
However, in line with our original question: is democracy needed as a precursor for sustainable development? Arguably, Rwanda presents a case where democracy, as viewed via western, institutional terms, is not the foundation of their development. Rather, the democratic institutions that are in place within the country act as a sort of theatrical buffer, a distraction or a ruse democracy used to appeal to developed country's leaders who occasionally chime in with their thoughts on Rwanda's development and as the 69 “year-old presides over a seemingly peaceful country, the west seems content" (Anonymous, 2017). With this in mind, and as we dive into the question of the necessity of democracy within sustainable development, it should be examined what kind of system Rwanda has established and the institutions in place that have lended themselves to the so-called economic success of the nation.

Hilary Matfess, in her work Rwanda and Ethiopia: Developmental Authoritarianism and the New Politics of African Strong Men gives us a great outline to the way the Rwandan government operates within the fabric of sustainable development. While Rwanda, as discussed, is a nation often characterized by its high growth and formal institutions of democracy, their civil society is often stunted due to the stronghold the government has on the daily life of the people. Matfess defines Rwanda as a “'developmental authoritarianism,'referring to nominally democratic governments that provide significant public works and services while exerting control over nearly every facet of society" (Matfess, 2015). She argues that there are five steps in which developmental authoritarians assume power, President Paul Kagame being an example of this. The regime is unified and justified to power, "following a major social rupture" (Matfess, 2015) and, upon their ascent, impose major restrictions on typical civil rights found in the developed world such as free speech, association and identity. This is usually justified by manipulating the social rupture, the 1994 genocide, and thus, grants an enourmous amount of 
power to the ruling autocratic regime, which is supported by the populace who endured the horrors and hardships of the past conflict. Paul Kagame, in his rise to becoming the leader of Rwanda, solidified his grip on power legally and internationally during the Arusha Accords, following the genocide, where the Funadamental Law of Rwanda was, single handledly, changed by the RPF. While under the Arusha Accords, power was to be shared amongst Hutus and Tutsis, the "amended Fundamental Law was, in effect, a subtle piece of constitutional engineering which attempted to mask the consolidation of the RPF's hold on political power" (Reyntjens, 2004). Matfess continues stating that developmental authoritarians tend to be very involved in the economy, promoting a free market approach, which gain them favor within the international economic sphere, as well as tend to be a "party-organized, militaristic mobilization of the population for development efforts" (Matfess, 2015), a concept seen within the conflict between Rwanda and the Democratic Republic of the Congo, a conflict that has lasting reminders of the 1994 genocide and revenge genocide campaign of 1996 and which continues to this day. Lastly, developmental authoritarians have an uneasy relationship with their neighbors, like the DRC, but also tend to garner favor from western powers while simultaneously rejecting their notions on human rights and democracy.

So what does the Rwandan political and civil structure look like today? Much of the country's political infrastructure has the allure of democratic development, having national direct elections for the president and the national assembly while the "the electoral system for local elections up to the level of the Senate is indirect" (Anonymous, 2020). The country's leaders are broken down into district counselors (Akarere), sector counselors (Imerenge) and cell counselors (Utugari), who are just above the last level of village representatives. "The Senate has 26 members. 12 senators are elected by the district councils, while two are elected by university 
staff. 12 senators are appointed by the president and four appointed by the National Consultative Forum of Political Organizations (NFPO)" (Anonymous, 2020). As of now, the country is a multiparty democracy "with regular elections, which lend an aura of legitimacy to their rule within the international sphere" (Matfess, 2015). All in all, with the economic miracle and the democratic structures in place, Rwanda has generated a mask of legitimacy within the international sphere when it comes to falling within the definitions of what it takes to be a development darling. However, upon a deeper analysis it becomes very clear that, while there have been great successes in Rwanda both politically and economically, the country's foundational structures are far from being along the international definitions of sustainable development and far from being foundationally sound.

Political Scientist and Great Lakes scholar Filip Reyntjens unveils in detail the facts about Rwanda's governance in his work Rwanda, Ten Years on: From Genocide to Dictatorship. While Reyntjens describes a country that has achieved "rapid institutional reconstruction and relatively good bureaucratic governance, it has also concentrated power and wealth in the hands of a very small minority, practised ethnic discrimination, eliminated every form of dissent, destroyed civil society, conducted fundamentally flawed ‘democratizastion’ processes, and massively violated human rights at home and abroad" (Reyntjens, 2004). In regard to Reyntjens first point regarding centralization of power: this is absolutely the case and was described in an an International Crisis Group report where it was it was stated "the political parties that exist today in Rwanda are only tolerated if they agree not to question the definition of political life drawn up by the RPF” (Reyntjens, 2004). Again, we see this pluralization of the political party apparatus, but the validity is far from democratic and far from allowing dissenting opinions and voices to be allowed. Political inclusion is a facade where 'shadow parties,' who align 
themselves with the RPF, do so without truly generating anything outside the ideological monolith that is the RPF. While this specific work was generated ten years after the genocide (2004), the country's system hasn't changed and has arguably become worse as new political figures have emerged to challenge the Kageme regime. In the 2010 election, "opposition parties such as the Democratic Green Party and the FDU-Inkingi party were prevented from registering in the months leading up to the election; further, organizers of the FDU-Inkingi party were subjected to physical violence when they attempted to register voters, with police officers looking on" (Matfess, 2015), demonstrating the government's grip as not only was this violence observed by armed police forces, but tolerated and allowed. Furthermore, in a report drafted by the BTI Transformation Index it was noted that "due to the exclusion of competing candidates and political parties other than the RPF, the local councils and committees do not function as organs of political participation, inclusion or power-sharing" (Anonymous, 2020).

Filip Reyntjens expands on this point of political repression further in his 2020 work Rwanda. Reyntjens notes that political shake ups, as have previously mentioned, specifically in the cabinet (closest members to the president), as well as with political dissidents, are common when perceived threats to the regime or counter-genocidal-narratives ensue and gain public attention. Earlier in 2020, amidst the pandemic, "on 9 April Minister of State Olivier Nduhungirehe was removed from office 'for consistently acting based on personal opinions over Government policies"” (Reyntjens, 2020). In a tweet, Nduhungirehe argued that "politicians who were killed during the genocide should also be remembered" (Reyntjens, 2020), which resulted in heavy backlash, arguably because it goes against the standard narrative of the genocide within Rwanda. Lonzen Rugira, a writer and editor for the Rwandan based news source The New Times, rebutted back against this comment, arguing "personal circumstances cannot be used to 
undermine collective memory" (Reyntjens, 2020). What should be observed here is The New Times, while it claims to be privately owned, originated in 1995 right after the genocide and tends to be sponsored and supportive of the Kagame regime, outcasting those who recite any sort of narrative against the RPF's depiction of events that occurred from April through July of 1994. Rugira later hinted at the fact that other political potentials, Victoire Ingabire (2010 political opponent of Kagame), in the past have tried to recite a new narrative, allowing people to 'mourn their own.' Ingabire ended up in a Rwandan prison with a sentence of fifteen years and has not been allowed to leave the country without permission from the Minister of Justice, who has refused to acknowledge her two requests. Her family remains in her exiled home, the Netherlands, to which she has not seen in the last ten plus years. Ingabire, in an interview with The Guardian, reflects on the difficulties of the Rwandan development model stating "there is a pattern of limiting political participation to those
affiliated to the ruling party and excluding serious contenders in
Rwanda's presidential elections. This is done by fabricating
charges and abusing the judicial system. These acts represent a
violation of Commonwealth core principles. They also challenge
the claim often advanced by the ruling circle in Rwanda that the
established political system is based on power-sharing consensus
democracy with the intent of overcoming ethnic divisions and
accelerating development" (Umuhoza, 2021). This disarming of political opposition and those who go against the narrative is not isolated to just the political world in Rwanda, but also in the military leadership as on "27 April, Kagame removed General Patrick Nyamvumba from the post of Minister of Internal Security “owing to matters of accountability under investigation" (Reyntjens, 2020). He was the shortest serving military leader under the regime's history and due to the fact of his short-term, Reyntjens suggests that his treatment may have been due to issues within the military establishment and Kagame, although this has yet to reveal itself to public news. Oustings are nothing new in 
Rwandan politics and, of course, these shake ups lead to open positions in which RPF/Tutsi

leadership are able to monopolize and dominate the political institutions within the country.

"As was the case in the past, the government's composition contravenes article 62 of the constitution which stipulates that a party cannot have more than 50 percent of cabinet members. However, out of a total of 31 members, the RPF holds 22 positions, with the PSD having two and the PL one; five members have no official party affiliation, and the affiliation of one other could not be identified. A more covert way of controlling the government, that has also been in use for many years, is that if a minister is not a Tutsi of the RPF, the permanent secretary is (with just one exception) a Tutsi of the RPF, thus offering a way of controlling members considered "less reliable". While they constitute under 15 per cent of the country's population, Tutsi occupy 60 percent of cabinet positions. In terms of both party political and ethnic affiliation, these figures have remained relatively stable over the last decade (Reyntjens, 2020).

Over Kagame's time in office, his grip on the political machine inside Rwanda has expanded, bringing in ethnic tendencies within the government. As Reyntjens notes, the majority of political positions within the Rwandan government are held by the minority ethnic group, the Tutsis, making us question whether much of these tensions have changed under Kagame's miracle country (see table below and appendix attached).

Table 1. Distribution on key offices - mid-2000

\begin{tabular}{|l|l|l|l|l|}
\hline Institution & Tutsi & Hutu & RPF/RPA & $\begin{array}{l}\text { Other Party/no } \\
\text { party/unknown }\end{array}$ \\
\hline Government & 12 & 8 & 11 & 9 \\
\hline $\begin{array}{l}\text { Permanent } \\
\text { Secretaries }\end{array}$ & 10 & 2 & 10 & 2 \\
\hline $\begin{array}{l}\text { Provincial } \\
\text { Governors }\end{array}$ & 9 & 3 & 11 & 1 \\
\hline Ambassadors & 7 & 3 & 8 & 2 \\
\hline Parliament & 49 & 25 & 61 & 13 \\
\hline
\end{tabular}




\begin{tabular}{|c|c|c|c|c|}
\hline $\begin{array}{l}\text { President's } \\
\text { Judges: } \\
\text { Supreme Court } \\
\text { and Court of } \\
\text { Appeals }\end{array}$ & 7 & 3 & - & - \\
\hline Army Command & 8 & 0 & 8 & 0 \\
\hline $\begin{array}{l}\text { CEO- } \\
\text { Public/Mixed } \\
\text { Enterprises }\end{array}$ & 17 & 5 & 18 & 4 \\
\hline
\end{tabular}

Note: Table 1 in Rwanda: Ten Years After the Genocide; Reyntjens, F. (2004).

Rwanda, Ten Years on: From Genocide to Dictatorship. African Affairs, 103(411), 177-210. http://www.jstor.org/stable/3518608

Furthermore, this blatant disregard for human rights, demonstrated within democratic states

(freedom of speech, press, political affiliation etc) have been widely eliminated under Kagame and the RPF, many times, as will be seen later, in brutally violent conflicts which have even expanded to outside of the country. In an open letter written by the then executive director of Human Rights Watch in Los Angeles, 2009, Kenneth Roth
"observed that even a government that does many good things does not have license to ignore human rights when it finds them inconvenient. Political pluralism, free expression, and genuinely competitive elections are not optional in a genuine democracy, but essential. He argued that no one should be allowed to manipulate the 1994 genocide to play on the heartstrings of the international community and thereby justify repression" (Roth, 2009).

Much of Roth's observation echos the sentiments of the international guilt syndrome held by the international community, specifically those in the west who delayed in coming to the aid of the Rwandese during the genocide. This, in itself, has become not only a tactic of Kagame's foreign policy, but also a narrative that, when challenged, results in brutal repression within the state. A lot of this narrative is engrained in the younger population in Rwanda through the application of 
the Ingando, or camps that are compulsory for civilians prior to university attendance. This disturbing control over the narrative and state's affairs through the Ingando is a practice that goes back and reflects Matfess's terms regarding developmental authoritarianism. However, while the state attempts to control the mindset of the people through these camps and political practices, I have found that more and more Rwandese are speaking out about the political exclusivity and the danger it poses to maintaining development in Rwanda.

\section{Indoctrination- Ingando:}

Within the Rwandan development criteria, especially Kagame's 2020 Vision, (which has now been moved to in light of the COVID-19 pandemic's impact on the economy) came the concept of Ingando, which the government claims is " is simply an updated version of a Rwandan tradition ....the idea of using ingando to cultivate reconciliation in Rwanda was born of meetings at Urugwiro State House in the years following the genocide.”(Mgbako, 2005). The word itself derives from the country's language, kinyarwandan, the verb “kuganika, which refers to a process in which the elders of a community would leave the distractions of their daily lives and retreat to places of isolation to solve problems of national concern such as war, famine, drought, and the expansion of the nation's borders (Mgbako, 2005). Additionally, while in line with the country's cultural and ethnic roots, the goal of the project was also part of the reconciliation process that began after the horrors of the genocide. However, while this idea of reconciliation and cultural unity seems great, and in many ways is important to the country's bond, the true purpose, having been documented and accounted for by government officials and militants, is far more political in nature and meant to serve the strengthening and progression of 
Paul Kagame and the RPF. It also eludes back to our discussion on how authoritarians operate using control of public opinion over violence.

The state-run mass mobilization effort of Ingando, are camps that are coordinated and run throughout the country and have been "alternatively known as 'solidarity camps,' 're-education camps,' civic education camps, ' 'political awareness camps,' reorientation camps,' and reintegration courses"' (Matfess, 2015). Originally, the target of these camps was mainly at former militants, returning Tutsis and government leaders following the genocide, but it seems clear today that the goal of the RPF is to have mandatory attendance for all students before attending university. "In a series of interviews with government administrators in January, 2014, a number of officials stated that part of the government's vision for 2020 is that all citizens will have attended Ingando” (Matfess, 2015).

But what exactly are these camps and what happens inside? From interviews with officials and those who have attended Ingando "the camps themselves are modeled after military training camps that the RPF established while based in Uganda" (Matfess, 2015), prior to the genocide. As Chi Adanna Mgbako describes

Ingando is more likely a pre-war RPF creation aimed at grassroots mobilization for RPF campaigns. From 1990 to 1993, the RPF installed participants in ingandos or "RPF schools" for three weeks, after which participants would be expected to return to their villages and disseminate pro-RPF ideology. This RPF practice may have occurred in Uganda and the RPF-controlled territories in Rwanda. In addition, the RPF, whose ideological mentor is Yoweri Museveni of Uganda, may have modeled ingando on solidarity camps in Uganda (Mgbako, 2005).

The daily structure of the camps follows a rigid schedule, including exercise and lectures from government officials. Opposing thoughts to the RPF ideology are not tolerated within the camps and according to Mgbako the lectures are composed almost entirely of RPF representatives. 
Today the concept of Ingando has expanded to other areas of Rwanda. Judges within the Gacaca courts, community leaders, women's groups, church leaders and students are all targeted with the goal of highlighting "the defects of the genocidal regime, and lessons on present government programs and policies that stress the 'democratic' elements of the current government" (Mgbako, 2005). As seen, the RPF has made it just about compulsory to attend these camps in which indoctrination into RPF ideology can be mandated, controlled and distributed amongst the population. The narrative of current politics, the genocide, Paul Kagame and the runnings of the country are tightly controlled within these camps and spread a sort of manipulation throughout the country, stressing democratic tendencies, yet enforcing a certain narrative to follow. Not only is there little separation from within the country's political foundation, but there is also little separation, so it seems, amongst the people and the executive's ideology on how the country should operate. While democratic tendencies can be 'stressed' within these camps, and publicly acknowledged, the Ingando demonstrates Kagame's dire need to control the narrative amongst his own people. Over and over, the government has publicly stated the intentions for these camps are for state unity and reconciliation, however, former participants stated in anonymous interviews that "outsiders say ingando is a way of attracting the youth to the Rwandan Patriotic Front...But if you feel that way in this country, you must keep silent" (Matfess, 2015).

In addition to citizens, people in office and position, the RPF has also heavily targeted ex-combatants who have fought in the Democratic Republic of the Congo during the Congo Wars (1996-1997/ 1998-2002). In summary, this conflict was a result of past tensions between the two countries, but was primarily sparked by the exodus of Tutsis fleeing Rwanda during the 1994 genocide and Hutus fleeing the country once the RPF army, under Kagame, took control in fear of retalation. Within the DRC, infighting began within the refugee camps located along the 
border of the DRC and Rwanda between Tutsi and Hutu refugees. Furthermore, the RPF made brutal advances into the Congo, aiming to hunt down génocidaires responsible for committing acts during the 1994 genocide in Rwanda, leading to a what is reffered to "revenge genocide," which has sparked international outrage amongst human rights groups, but tends to not be acknowledged by global leaders. This march into the Congo led to brutal and violent measures taken at the order of Kagame and, to this day, still holds an uneasy border tension between the two countries. It is amongst those who were mobilized to fight in the Congo, and their subsequent de-mobilization, where Kagame's authoritarian control used within the ingando can be seen yet again.

As Chi Adanna Mgbako describes in her work Ingando Solidarity Camps: Reconciliation and Political Indoctrination in Post-Genocide Rwanda Note, "it is presently compulsory for ex-RPF, ex-FAR who did not flee to Congo, and ex-combatants who fought in Congo (ex-Armed Groups) to attend ingando camps as a pre-demobilization, pre-discharge orientation program" (Mgbako, 2005). Similarly to the citizen and political population in Rwanda, ingando preaches a very specific narrative regarding the RPF, Kagame and the political measures taken within the country in order to re-integrate ex-combatants back into society with a matching and positive view of current RPF doctrine. Additionally, the ingando camps, along with financial reparations are also being offered to ex-rebels and génocidaires as well as the government states "if it does not assist these rebels in peaceful resettlement they will revitalize the insurgency" (Mgbako, 2005). Along the lines of reintegration, it does seem vital and a positive step forward to try and reintroduce combatants (on both sides) back into society, however, as noted

People working in the nongovernmental sector compare ingando with other 'unity and reconciliation' activities saying 'ingando is different, it is more political.' Ingando are indeed fundamentally political, not only because i) politics and specific policies are being 
taught ('in ingando the government makes its programme being known'), or because ii) convergence and 'defence' of policies ushers support to ruling party, thus solidifying its grasp on power; but also because iii) the state takes a keen interest in these specific groups and their 'forming,' re-working, essentially their wholesale transformation, into an 'ideal citizen' (Purdeková, 2011).

As Purdeková notes, the 'ideal citizen' is one that is molded and formed according to RPF ideology, an ideology that dictates the thoughts and values of the population, which in turn can shape the national discourse. The results of this are an overwhelming support for the monolithic vision that is the RPF and its unseparated legislative and judicial control within the country. As ingando becomes compulsory, so too does the state's absolute vision and control, thus, arguing the point that freedoms guaranteed within democracies indeed do not exist within this indoctrination apparatus, but an authoritarian control over the minds of the nation's constituents, which has undoubtedly led to a uniform vision about what development means and looks like for the country. Overall, the nation's constituents are supportive of Kagame and his work as it resembles progress from what was to the development success of what is. But with this development, as we can see, comes the sacrifice of individual freedoms and liberties of thought and mind. While this can, and has in the short term, lended to Rwanda's ability to stay relatively peaceful, in the long run, especially with social media platforms exploding within the country and more dissenting voices being able to be heard, will this not spark change? Will this not question Kagame's benevolence?

Amartya Sen discusses the imperative point of social interactions within development and how they are imperative to its success. Sen notes that "the politics of social consensus calls not only for acting on the basis of given individual preferences, but also for the sensitivity of social decisions to the development of individual preference and norms...in this context particular importance has to be attached to the role of public discussion and interactions in the 
emergence of shared values and commitments" (Sen, 1998). This is an excellent point to stress and points out the fallacious comments from the government about reintegration and reconciliation: if the public discourse is compulsory attendance to ingando, which in turns morphs the individual's mindset to be in line with the ruling party's doctrine despite truths, does this in turn actually create a system that is sensitive to the development of individual preference within the country? From a development standpoint, and in regard to the necessity of democratic freedoms within developing countries, it seems to create a conundrum in the state of Rwanda. These mandatory indoctrinations, while creating a sense of 'unity;' which has in turn brought the country's population on board with Kagame's vision for economic development (which on paper has occurred), have come at the cost of social liberties and freedoms which has created an "us" versus "them" mentality amongst the population, a mentality that helped lend itself to the atrocities in 1994. While ethnic identification in the country has been pushed aside following the genocide, and it being the roots of it, it has been replaced by the concept of being either in line with the government's rule and narrative or fear, repression and potential violence for those who stray away.

The treatment of people within ingando and those who have refused it has been widely reported on. In the Immigrartion and Refugee Report of Canada, Rwanda: Information on ingando camps, including organization, structure, programs and participation; instances of human rights violations in the camps it was reported in 2013 that " 14 men and 2 women fled Rwanda and sought asylum in Uganda, claiming they had experienced "harassment by officials" for refusing to attend an ingando program in Butare, 80 kilometres from Kigali ... The students claimed that as a result of their refusal to participate in the program, authorities withheld their high school examination results" (Anonymous,2014). Upon more investigation, the students 
reported how many of their friends who had attended the camps were pressured to join military groups, specifically M23, a Rwandan backed rebel group in the Congo. Out of this fear, the students claimed they wished not to attend the camps for fear of military service as "most of their friends who went there never came back" (2014). Another report from a 25 year old masters student "who attended ingando in 2008 said that the program 'taught us how to contribute as soldiers, not as intellectuals'"' (2014). The brutality of the camps, having been established in a military like format, saw the usage of beatings, sometimes with a whip, to ensure obedience within the camps.

When it comes to the impact of ingando, one student in a report Rwanda's Ingando camps Liminality and the reproduction of power, a "student suggested, 'I don't think that [ingando creates reconciliation]. You can show people that you agree, but in your head you think another thing... You cannot tell it because otherwise you will be imprisoned" (Purdeková, 2011). In another report a researcher noted

When these kids go through ingando, something happens, there is a feeling of fear [in them], they are only afraid of the challenges, of history, [they] know only of the government's programme. That is why I hate them [ingando], I never went to visit one, but I can see the outcomes. There are no demands, they demand nothing, there are no demonstrations, no strikes at universities, I keep thinking this must be the result of ingando. Another result, and you cannot observe it because you are not Rwandan, if you meet former soldiers, prisoners, former ingando trainees, even in family context, and you start to criticise or to have contradictory opinions, they just laugh a little and say nothing, whether Hutu or Tutsi it does not matter, nothing, no opinion. (Purdeková, 2011).

This quote acknowledges our point regarding social politics and the ability to discuss and create unity from an organic place rather than an enforced ideological narrative. While I cannot back the notion with fully grounded evidence that the lack of strikes of opposition comes from the 'brain washing' narrative that is pursued amongst the ingando camps, it can certainly be seen, 
from the accounts listed, that it can be inferred and perhaps correlated at the least. As Purdeková notes the "Ingando's effects thus can be seen from a different angle, a much more politicised one... Ingando can be seen as a key tool in, and a microcosm of, the wider political project of governmentality and social engineering” (Purdeková, 2011). However, as new voices arise within and outside the country, it must be asked how long this program's effect can last.

\section{Indoctrination 2.0- The Gacaca Court System}

The concept of social engineering to maintain a monolithic narrative does not stop, nor end, at the ingando camps or through oppressive measures as I will examine when looking at the press, both domestic and foreign, in Rwanda. After the genocide, a court system was established in Rwanda to handle the reconciliation process within the country and pursue a pathway to moving forward after the atrocity. The Gacaca court system was promoted as a "Rwandan solution to a Rwandan problem; the claim that large numbers of foreign journalists were not what was required, and that justice in Rwanda would be done by Rwandans" (Matfess, 2015). Additionally, due to the sheer volume of perpetrators (genocidaires) the justice system had to take on, the courts were established as a way to handle this massive influx to the country's redeveloping judicial apparatus. From an international point of view, it should be noted that this would seem a good step in the right direction: a country taking on this issue in its own way should be noted and acknowledged as a positive step forward into bringing the country back together after such horrible events occurred. It even hints at notions of democratic change within the country, to allow the citizens a pathway to forgiveness, reconciliation and reintegration back into society. In fact, "Rwanda's Gacaca courts have long been held up by their proponents as a 
model for successful, post-conflict reconciliation efforts" (Seay, 2017). In the aftermath of the genocide, while most of the main leaders of the genocide went to the International Crimnal Tribunal of Rwanda (ICTR), located in Arusha Tanzania, Rwandan's solution was the traditional court system of Gacaca, consisting of " 12,000 community-based courts that sought to try genocide criminals while promoting forgiveness by victims, ownership of guilt by criminals, and reconciliation in communities as a way to move forward" (Seay, 2017).

Upon a closer examination, however, we find an unsettling truth of more social engineering constructed by the Tutsi dominated RPF, and the "development of an approved official narrative of the genocide" (Matfess, 2015). In other words, the "gacaca process was far more political and much less conciliatory than the casual observer might want to believe" (Seay, 2017). From its genesis, the Gacaca system was utilized in delineating a strict system of 'what happened in Rwanda' and what absolutely did not. As stated, reconciliation within the ingando system heavily promoted and, in other words, forced Rwandans to be educated in a certain way regarding the genocide and how to think about it. The Gacaca system, similarly, has been used to promote this exact ideology, but instead of being aimed at the youth Rwandans, it was aimed at those involved in the genocide or those who think outside the borders of thought process when it comes to the narrative. As one government official from Southwestern Rwanda involved in unification and sensitization stated in an interview

The goal is to make people have the same opinions. It is very important that people in Rwanda think the same way because we need unity in this country. What we hope to achieve is that after a meeting, 75 percent of the people leave with the same mindset. Those people will also talk about what they have heard with other people, so that we will reach almost the entire population (Matfess, 2015). 
Unity and legitimacy dominate the Gacaca system and how the RPF maintained its dominance in the country via judicial process. If people think the same, questions will be minimal or easy to dismiss, but of course this is incredibly dangerous to any sort of democratic foundation within a developing country and is, in essence, no different than historical tyrants controlling the official party narrative within their respective countries; Joseph Stalin's promotion of Leninist communism or the Kim Dynasty of North Korea being some examples. Facts were distorted and those who deviated away, in many cases, disappeared.

Arguably, the courts do achieve a sense of justice throughout the country by utilizing the system, which incorporates Rwandan cultural and traditional roots, but it's the manner in which it was used that articulates autocratic rule in the country rather than a judicial system abiding by democratic principles. In her book Investing in Authoritarian Rule: Punishment and Patronage in Rwanda's Gacaca Courts for Genocide Crimes, Anuradha Chakravarty elabortes on the politics behind the Gacaca, explaining "the Tutsi-dominated Rwandan Patriotic Front (RPF), used gacaca courts as a tool of patronage to build the new, post-genocide government's legitimacy, which in turn allowed the RPF to entrench its rule into the virtually unchallenged authoritarian system in Rwanda today" (Chakravarty, 2015). In fact, while the RPF's beginnings are rooted in horrific violence and brutal repression, both domestically and abroad, specifically in the Congo, Chakravarty explains how, over time, the Gacaca system became a sort of mutual benefit between the Tutsi dominated RPF and the Hutu majority. Rather than resorting to violent means or repression, as many totalitarian rulers do, Kagame and the RPF used the courts as a way to promote and solidify their rule by enforcing the narrative upon those in the courts and using them as the promotional tool. She writes 
In denouncing others, submitting self-incriminating confessions, and judging their friends and co-ethnics, thousands upon thousands of individual Hutu acted upon and enforced RPF rules, reinforcing the regime with their cooperation in exchange for reduced sentences, security guarantees, the possibility of private gains in the form of personal vengeance or economic windfalls, and opportunities to access public power and social prestige. The RPF unleashed a stream of individualized benefits and sanctions that made "opportunistic investors" of ordinary Hutu who backed RPF rule in their own interests (Chakravarty, 2015).

Can this really be considered true justice? Furthermore, how stable is a system like this and how does it impact the democratic development process of a country like Rwanda? Of course, those who deviate from the official narrative "which stresses national unity to the point of obscuring continued inequality and tensions between Hutu and Tutsi, can result in imprisonment" (Matfess, 2015). As noted, leaders such Victoire Ingabire Umuhoza, who started a new political party, the United Democratic Forces of Rwanda (UDF-Inkingi) to challenge Kagame in 2010, was sentenced to eight years in prison and later, when appealing the case to the higher courts, fifteen years, demonstrating the amount of executive control the party's leader has over the entire governmental system and those who dare to run against or challenge its authority. In more extreme cases we have seen the murder of challengers such as "vice-president of the Democratic Green Party, André Kagwa Rwisereka, who was murdered in 2010 and the former head of intelligence, Patrick Karegeya, who was murdered in 2013" (Umohoza, 2021). It seems very clear that a country which stresses the idea of democratic values, especially checks and balances within the set up of the governing body, the RPF and Kagame maintain an iron fist on those it feels are outside the molding of contemporary Rwandan thinking. This, of course, only generates a system of fear and absolute obedience to the narrative. 
Indeed, the Gacaca courts, as well as other courts in Rwanda, have indeed expressed and promoted RPF autocratic rule within the country and while the results of the Gacaca system have indeed entrenched authoritarian rule within the country, it is important to acknowledge, as Chakravarty explains, that this perhaps wasn't the intention. Following the RPF victory in Kigali on July 4th, 1994, and the establishment of these courts throughout Rwanda, Hutus and those involved in the genocide, really had few options in regard to how to move forward with in the country post the genocide. It seems clear that the options were to either flee the country, which in many cases resulted in brutal, retaliatory violence by invading RPF soldiers in the Congo, or face the court system. Thus, it's very clear that as Rwanda emerged from the horrors of the genocide the "RPF was the only option for any Hutu seeking to gain better status or avoid worse punishment for crimes, those Hutus had no choice but to work within the RPF's system of patronage, but this did not mean that most Hutus accepted 'that the RPF were legitimate rulers with the requisite clean hands"' (Seay, 2017). That being said, we see that not only was the narrative inducted into the minds of Rwandans going through Gacaca, but also involved pursuing genocidaires who weren't participants in the genocide at all. Chakravarty continues with this stating the incentives offered to Hutus through Gacaca "led to negative outcomes for many Rwandans, particularly those who were falsely accused of participation in genocide...faced with competing loyalties to different family and clan members alongside the need to demonstrate commitment to the gacaca courts, made decisions about whom to denounce and at what times to do so" (Seay, 2017). While on a local level within the country, Gacaca has maintained forms of local peace between those who perpetrated and those who were victims of the genocide, it falls on a double-edge sword of justice that is maintained by authoritarian rule. Thus, it must be asked 
how stable and long lasting is this justice, especially when the political, legislative and judicial structure are dominated by the party that enforced the Gacaca indoctrination?

The Gacaca system, while perhaps initially intended to seek out justice within Rwanda and provide a judicial route to reconciliation, actually created a path to a more solidified autocratic regime. The courts have been used to induct Rwandans into a specific way of thinking and, creating a sort of governmental facilitated, social engineering experiment which in many cases, created a justice system that has actually pushed those with their own opinions or political challenges into prison or worse, death. It is within these institutions that we blatantly see the lack of true civil, judicial and political, democratic development in Rwanda. In Senian thought, development is measured through the amount of freedoms individuals have within a society. However, when going through Sen's list of imperative freedoms in regard to development, under the RPF rule, Rwanda falls short in many ways. Political freedoms are out of the question as demonstrated by those who challenge Kagame for leadership in Rwanda. Social freedoms and security guarantees are, in many ways, stripped unless you fall within the narrative. Freedom of thought exists in Rwanda, but only in the shadows or within one's head. Those who speak out of line risk the wrath of the ruling elite. While it must be acknowledged that Rwanda's Gacaca did develop a system of justice, that very system has also helped to plunge the country deeper into authoritarianism. But when examining this in regard to our question of the necessity of democracy, how should this be answered? While perhaps the system is plagued with issues that, from a western point of view, would seem damming, does this actually insist that the country is worse off? 


\section{Deviating from the Story: Disappearances, press suppression and international condemnation.}

As I have explored, Rwanda's judicial practices and social engineering systems are the manifestors of the official narrative and definition of contemporary Rwandan thought in regard to the history of the country as well as how it should look moving forward. Perhaps put a little differently, Kagame and the RPF have made it very clear as to what it takes to be within the 'in' part of society as well as demonstrated the consequences to those who do not fit that mold. Domestically, there is a uniformity that all must fall into. A monolith of reasoning and thought that allows the country to move forward. The lack of separation of the "democratic" institutions from the executive in Rwanda has created a country where "the Rwandan people know that to survive in such an environment, and to benefit from any government- or foreign-funded aid, they

must be loyal to their president" (Sundaram, 2014). Let us be very clear: I am not saying Rwandans are incapable of having social and civil freedoms. Quite the contrary, it is the fact that Rwandans, out of fear of harm from deviating from the nationalistic emphasis engrained in them through the ingando or gacaca, are unable to freely speak their mind. It is within these institutions that the very question of this paper comes into focus. Controlling the historic narrative of a nation, and condemning and punishing those who question it, is dangerous and, as history has shown with other historic dictatorial leaders, extremely unstable in the long run. While asking about the integrity of democracy in development, we see that Rwanda demonstrates a case of a ruse democracy, which analogously has a sort of gilded appeal. On the surface, Rwanda oozes what international leaders, specifically in the democratic west, want to see: a nation rise out of the ashes of a horrible atrocity and take on democracy as its development 
model. However, as beautiful and wanted as this is, it simply isn't the case. Underneath the darling that is Rwanda lurks a regime that will do what it must to command the minds of those it rules over. While there has been great success within the country's economic growth (a common point noted and attributed to Kagame's rule), it must be questioned as to how long this can actually last and whether or not this growth is based on the actual implementation of economic practices through Kagame's leadership or foreign aid dependence. The latter of these points will be a major discussion later in this work, articulating the true nature and fundamentals of how Kagame financially operates the country.

In the international sector, Kagame has been questioned in regard to his role on human rights, or lack thereof, and how, in addition to his overall rule within the country, this contributed to legitimize his "democratic" rule over the country. As discovered, those who defer from the narrative of Kagame's Rwanda have seen the wrath of Kagame first-hand, but it is also important to understand how Kagame presents his role to both the domestic and international media. Indoctrinatization practices, as I have analyzed, have been widely used throughout the country, but so too has a suppression of the press, which has been widely seen as a tool to further emphasize the narrative story. The expert use of suppressing or dominating the press is what I will be exploring next as it helps to emphasize our discussion regarding international knowledge of how Kagame rules and details the paradigm of foreign aid in development, an aid that Kagame is more than addicted to. Kagame's international title as the "darling tyrant" is no secret to foreign leaders as international headlines in human rights magazines and foriegn journals have documented this clearly throughout his rule, yet foreign aid still makes its way into the country, and consistently. Why? In this section, I will examine how Kagame handles the press and uses 
his status as the "development darling" to articulate and, perhaps, redefine how democracy is understood in non-western, economic terms.

In February, 2019, in a speech, Paul Kagame gave a warning to his online critics stating "they are close to the fire" and one day "the fire will burn them" (Mudge, 2020). As technology advances and the ability to access online platforms such as YouTube, Instagram and Twitter make their way throughout Rwanda's virtually connected audiences, so too does a new form of political dissidence that, as seen, Kagame has publicly warned not to go too far into. Though technology advances, the tactics do not as suppression or control of the press is very much the same as suppression of political opponents who criticize Kagame's thin skinned leadership and has been a trend even since his first years in office. As early as 2001, one year into Kagame's first term as president, early reports from French papers came out analyzing the situation of the press in Rwanda noting "reporters from Sans Frontieres described Kagame as 'a predator of press freedom' and noted that only one weekly, Umuseso, was 'relatively independent" (Reyntjens, 2004). Upon the release of this report, one of the journalists from Umuseso went into exile while two others were jailed, portraying a country, early on in its development, where those who criticize or point out the flaws face only fear and punishment. In recent years, the same acts have occurred with others in the country as well. In 2019, Human Rights Watch reported "Eugène Ndereyimana, an opposition member with the unregistered Forces démocratiques unifiées (FDU)-Inkingi party was reported missing by his colleagues on July 15, 2019 after he failed to arrive for a meeting in Nyagatare, in Rwanda's Eastern Province" (Anonymous, 2019). In another case in the same year, HRW reported another missing reporter, "Constantin Tuyishimire, a journalist with TV1 Rwanda who covers northern Rwanda, was reported missing on July 16 while he was supposed to be on a reporting trip to Gicumbi District" (Anonymous, 
2019). In the same report, Lewis Mudge, the Central African Director of Human Rights Watch, stated that this is yet another in a long line of disappearances in the last year, advocating for the authorities to conduct a transparent investigation of these disappearances as it seems they were politically motivated. While we could sit here and list disappearances and mysterious murders of political dissidents, the point here is to elaborate on the unstable political situation this is creating in Rwanda from a development standpoint.

2020 shaped up to be an extremely difficult year for the globe and, of course, developing nations had not only the challenges of the COVID-19 pandemic, but also the challenges of development where Rwanda is no exception. As technology has boomed and allowed for more freedom of thought and, most importantly, expression, the Rwandan government has found itself in a more difficult stronghold regarding how it deals with suppressing those who deviate from the enforced narrative. In the last year, as the pandemic swept across Rwanda, even reporting on the facts and effects of the pandemic could result in severe legal punishment if it demonstrated that the Rwandan government had some pitfalls. As Lewis Mudge documented in a Human Rights Watch article,

Reporting on apparently innocuous - yet critically important topics like growing poverty under the Covid-19 lockdown, or the eviction of vulnerable populations from poor neighborhoods of Kigali, the capital, can land you in jail. Dieudonné Niyonsenga, also known as Cyuma Hassan, was the latest victim of the Rwandan authorities' thin-skinned approach to criticism. He was accused of a range of fabricated offenses including impersonating a journalist. Niyonsenga and his driver faced a year-long trial before being acquitted (Mudge, 2021).

Mudge further reported on the growing influence of YouTube as a major platform for criticisms against the Rwandan government during the COVID-19 Pandemic, citing the mysterious disappearance of Innocent Bahati: 
On February 9, 2021, Innocent Bahati, a 31-year-old singer and poet, was reported missing to the Rwanda Investigation Bureau (RIB), two days after he was last seen in Nyanza, Southern Province. His poems, which he recites in videos posted on YouTube, have focused on social issues such as growing poverty or criticism of the lockdown and its impact. Two people who saw him before he disappeared told Human Rights Watch that he had traveled to Nyanza district on February 7 to research material for a new poem. The RIB spokesperson told the media an investigation into his whereabouts was ongoing. Several sources said that Bahati was previously detained in 2017 for criticizing the decision to move the Kigali Institute of Education campus from Kigali to Rukara, Eastern Province. Given Bahati's previous detention, his recent criticism of government policies, and the pattern of mysterious disappearances of government critics in Rwanda, his disappearance should be treated as suspicious, Human Rights Watch said (Mudge, 2021).

As seen from the series of demonstrated accounts, Kagame and the RPF's iron first on Rwanda is clearly evident, but is also being exposed to those in the social media community. Those who sway away from indoctrination, the monolith ideology of the genocide or push back against RPF political moves find themselves in dangerous and, sometimes, violent situations. Yet, with all of this acknowledged, Rwanda still remains a development darling and a beacon of democracy within western thought. Why? I have demonstrated and shown that Rwanda, while having gilded democratic institutions, underneath the surface, is truly an autocracy ruled over by Kagame and the RPF who aim to create a uniform way of thinking across the country regardless of social freedoms being in tact. This, and the actions discussed, go against all Senian thought on democracy and freedoms that are considered needed for countries to develop. Yet, Rwanda averages seven percent growth and is "one of the leading African countries in economic growth. According to official figures, its investments in agriculture, energy, infrastructure, mining and tourism have lifted more than one million people out of poverty" (Anonymous, 2019). The country has strived towards gender equality where "sixty-two per cent of parliamentarians, fifty 
per cent of ministers and forty-four per cent of officials in the judiciary are women" (Anonymous, 2019). Within the educational sector, over 600,000 laptops have been delivered throughout the country and over $80 \%$ of the country is covered by a form of health insurance. Surely, these are positive developments, are they not?

In our final section, I will examine how the international community has helped Rwanda become this development darling while ignoring the blatant human rights violations. I will examine the funding that goes into maintaining RPF power and limiting political diversity, the goal here being to demonstrate that, yes, while an autocrat has maintained power and control over the country, much of the funding that has been put into developing Rwanda isn't actually from Rwanda. Furthermore, I will demonstrate that the successful economic statistics claimed by Rwanda have, in recent reports, being dubbed as fraudulent, thus, bringing to the spotlight the questionable longevity of this authoritarian regime.

The last point to demonstrate in this research is that democracy isn't necessarily needed in order for a country to receive financial aid for development, but it is in the country's interest to maintain the look of democracy, which Rwanda has done quite successfully. Although, in many ways, this has also pushed dissidents within the country to advocate for massive democratic reform within the country, creating a socio-political and economic situation that makes us question how long an authoritarian regime like Kagame's can maintain its grip on power. It is here that we see the true enigma that is development and how democracy is more of something that should theatrically appear, in a political guise-sense, for aid, but is not imperative for the country to create development within itself- rather, as in the case of Rwanda, this has created a aid dependency on the international community, a community that is now also, in a sort of indirect way, responsible for lack of social freedoms in the country. So approaching our final 
section it must be asked: in Rwanda, what is the role of democracy and how has development occurred in spite of the fact that autocracy reigns supreme in the country?

\section{Borrowing, aid, reports, development and sustainability:}

It should be of no surprise that supporting autocracies, especially those in favor with western interests, is not out of the question when it comes to democratic leaders who support developing nations. Especially for someone like Paul Kagame who, through his leadership, has transformed Rwanda "from a Third World backwater into a prospective middle-income country" (Mailafia, 2017), a feat not easy in the developing world. While critics and reports, including this one, have highlighted the ruses of the country's democracy, including the fact that it ranks 160th of 189 countries in the UN development index, it is still undeniable that mass progress has been made within the country's ability to develop rapidly after the 1994 tragedy. But how is this possible? In many ways, Kagame has been compared to other historic leaders who have used autocratic methods to develop their country, the most prominent being the Lee Thesis from Singapore. However, while I have argued that modern autocrats tend to focus on controlling the language and mind set of a people, which Kagame does and continues to do successfully, he also uses much more crude and obvious tactics to sway those from going against him. Nonetheless, Kagame remains a paradox in the international community due to his methods, but also the results he produces from the international community.

Rwanda is labeled as one of the most competitive, liberal and open economies in Africa, with land and health reforms seen across the country, attracting the eye of neoliberal, international institutions and countries alike. Technocrats and powerful leaders such as Bill Gates 
and Bill Clinton have all commented on Kagame's leadership and the success he has brought to the nation. While it is true, and this paper isn't arguing against the successes that have happened, on the contrary, the whole focus of this paper is to analyze the role of democracy in development and Rwanda has demonstrated a case of exactly that while at the same time pushing away basic human and civil rights. However, what should be examined and included in the discussion is the role of the international community when it comes to the development seen in Rwanda today and how this may demonstrate that Rwanda's autocratic leadership is not as responsible for as much of the development as many think- at least when it comes to the financial aid and support that Rwanda is given.

As I have discussed, the role of international guilt regarding the 1994 genocide, according to professor Reynjentes, is a huge part of the lack of condemnation regarding civil and social freedoms from other democratic nations. However, I would argue the ability for Rwanda to have such a hold on the international, democratic community is not a new phenomena, but it is also based on how they appear to the community. While in this paper I have shown time and time again the lack of political, civil, human, and democratic rights guaranteed in the country, that does not prove that Rwanda is incapable of interacting with western democracies, and successfully receiving massive amounts of funding. As Michaella Mattes and Mariana Rodriguez state in their work Autocracies and International Cooperation, "while democracies domestic processes' are conducive to their success in international cooperation, autocracies would seem to be challenged....yet is important to recognize that not all autocracies are equally disadvantaged" (Mattes, Rodriguez, 2014). In their work, Mattes and Rodriguez measure the cooperation ability between personalist dictatorships, military regimes and democracies from 1990-2014. Their results were "autocracies that more closely resemble democracies in the institutional 
characteristics that have been found to be important for cooperation (that is, greater leader accountability, limited policy flexibility, and greater transparency) should be more successful at cooperation and thus more likely to cooperate with one another and with democracies" (Mattes, Ridriguez, 2014). Using this information, Rwanda fits this mold in many ways. While the suppression of rights and political freedoms is common, their appearance as a democracy, with a check and balanced government, constitutionally guaranteed rights and their established institutions helps to pull in the international community. I would argue this, along with Reynjentes explanation of international guilt, are key factors in Rwanda's title as a development darling and its praise from the democratic west. In other words, Rwanda checks off the 'democratic nation' checkbox through their appearance rather than their actual practices; thus, the country receives higher amounts of international funding than many other developing countries within its geographic area.

So, we know that Rwanda checks off the ability to look democratic, but does this mean their development is organic and from within or is this development more so based on the international funding received? As a nation, the country has focused much of its dependence for domestic financial capabilities on the international community rather than from within. While "economic growth has been high in Rwanda, it is characterised by low per capita income, low private investment, low exports and high reliance on aid" (Umuhoza, 2021). As the country grew through 2010-2020 so too did its borrowing as, according to the International Monetary Fund, it increased its "indebtedness to 66\% of GDP in 2020" (Louis, 2020). Even prior to the onset of the COVID-19 pandemic, the country was already struggling and taking on higher amounts of debt, which of course just puts more strain on the economy.

Prior to Covid-19, Rwanda had a cash gap of $15.7 \%$ of GDP a year to meet its sustainable development goals by 2030 . 
This has increased to $21.3 \%$ of GDP per year. Given that its government was provided with significant financial assistance to support its development plan to transform Rwanda into a middle-income state over the past two decades, and has not succeeded, I would argue that any further financing must be accompanied by radical governance reforms. Current governance in Rwanda - that limits political space, lacks separation of power, impedes freedom of expression and represses critics of the government - cannot lead to sustainable development. (Umuhoza, 2021)

Of course, with the oncoming of the 2020 COVID-19 pandemic, the country has struggled immensely and the main economic challenges of "an undeveloped private sector, increasing unproductive indebtedness, high youth unemployment and a consistently high poverty rate, as well as a population happiness deficit" (Umuhoza, 2021) will continue to rock the country if it is not stabilized in the following years.

Rwanda borrows a lot from the international community. In fact, around " $30-40 \%$ of the budget - still comes from aid" (Anonymous, 2021). In a Systematic Country Diagnostic, conducted by the World Bank in 2019, Rwanda's performance, in comparison to other nations with a similar GDP per capita in the area, was abysmal. The report noted "Rwanda also appears to have relatively higher poverty than neighbouring peers with similar income per capita" (Anonymous, 2019). Currently, the country ranks 142 of 157 countries on the Human Capital Index, the predictor of poverty measurement. In fact, within this category, Rwanda was out performed by its neighbor, Burundi: a nation currently experiencing conflict and war. Continuing, "more than 70 percent of adults at the 40th percentile of population distribution or below (B40) have only incomplete primary or no schooling at all” (World Bank, 2019). Poor roads and infrastructure have made it difficult to connect the country and, from an open market point of view, the biggest domestic investor in the country is the RPF owned Crystal Ventures, a company noted to have $\$ 500$ million in assets. The company handles everything from finance to 
furniture, is the largest milk processor in the country, and handles the distribution of most coffee and pricy real estate throughout. Its only rival is a similar company named Horizon, which is responsible to the Ministry of Defence, a department dominated by the RPF. Over their years of investment, "Crystal Ventures and Horizon both get cushy government deals which mask the failures of their enterprises, several of which are said to be loss-making" (Anonymous, 2017). In an interview with former RPF presidential advisor, David Himabara (now living in exile) "they monopolise but they don't deliver on development" (Anonymous, 2017). In the same interview it was noted

To critics, the firm is the business wing of an authoritarian elite. It funded half of the party's election campaign in 2010. It sold a subsidiary in 2002 after UN experts accused it of trading in conflict minerals in the Congolese war. The business purpose for two private jets that are allegedly leased by Crystal Ventures to the president, Paul Kagame (pictured), is unclear (Anonymous, 2017).

As can be seen, even in the open market, corruption and authoritarian control run deep and have produced little results to development as backed up by the World Bank Report.

Potential foreign investors who have worked in Rwanda acknowledge that "poor, unfair, and

unstable regulations and exempting specific companies from regulation” (World Bank, 2019) have contributed to less foreign direct investment from companies. Furthermore, with Kagame's control on the market via his investment firm, the monopolization is a deterrent for many companies who wish to operate in the region and with the country. While proponents argue that it is good for a government, especially after a cataclysmic event such as the 1994 genocide, to control and operate the financing of the country, it is also good to know when to let the private sector in as "in the long run, creating such an extraordinary overlap between political and commercial power is dangerous" (Anonymous, 2017). Over time, companies like this can be 
used for selfish motives, which they have been, and potentially loot the country of its earnings. Thus, from a sustainable development point of view, authoritarian control over the market as seen in Rwanda, in the long term, can and very well has a high chance of being more corrupt and destructive to the nation's economy.

While the debate on the extent to which foreign aid is beneficial or detrimental to a country's development is beyond the scope of this paper, it is important to look at it within the context of democratic freedom. While other, minor political parties develop in the country, they are blocked from using any foreign assistance, yet Kagame and the RPF are allowed to use massive amounts of foreign investments to fund their political campaigns, which many of them do through their investment firms such as Crystal Ventures and Horizon. The hypocrisy is obvious, but what may not be is that when it comes to sustainable development, the international community of donors is actually helping to fund and sustain Kagame's iron fisted rule on the country- not create a more democratic system to which they, on paper, demand. In a United Nations resolution document titled 51/240 Agenda for Development "democracy, respect for all human rights and fundamental freedoms, including the right to development, transparent and accountable governance and administration in all sectors of society, and effective participation by civil society are also an essential part of the necessary foundations for the realization of social and people-centred sustainable development" (Anonymous, 1997). While this paper has looked closely at all of these violations that perpetuate consistently in the country, so too have I acknowledged and noted that the international funding has also increased over the years. Why? International aid goes straight to the priority of the government of Rwanda, which is controlled ruthlessly by the RPF regime, a regime that enforces autocratic measures to maintain its authority, even if that means breaking civil and human rights and, on several occasions, 
international law on a regular basis. Furthermore, as I have also proved the economic development of the country is not as high, great or darling status as many would like to think.

Even still, as aid pours into the country, as Umuhoza and other international financial institutions have documented, the country's debt and GDP have slipped or not grown as much as hoped. It seems clear, after examining the aid dependence, that perhaps Rwanda's economic success, like its democratic "experiment" is also a ruse, propped up by funding that pours into the country. Additionally, what little funding is generated seems to be concentrated among the wealthy through investment groups owned by the government elite. While the county has made great strides in many ways, much of this seems like a ruse to appear, in some way, democratic and, thus, economically successful. However, if the country remains under autocratic rule, like many other autocracies, I argue its sustainability will eventually collapse. It is important to remember "the overall goal of sustainable development (SD) is the long-term stability of the economy and environment; this is only achievable through the integration and acknowledgement of economic, environmental, and social concerns throughout the decision making process" (Emas, 2015). Unless Rwanda moves towards a more inclusive and open government, the tensions that still lay dormant in the country are bound to rise again.

\section{Concluding Remarks:}

At the beginning of this research, my intent was to analyze sustainable development from the viewpoint that democracy and democratic freedoms were not an imperative part to a country's overall development strategy. Using Rwanda as a case study, due to its rapid development after the genocide, I figured that it would be a perfect example of a country who 
has swayed away from democracy and has continued to show an ability to develop sustainably. However, as I continued to research and dug into the country's political and economic history, more and more information altered and eventually changed my conclusion. In the process, I have found two concluding arguments in regard to the necessity of democracy and the political freedoms that come with it that lend themselves to their vitalness in sustainable development. While in the short term, economic development and success has surely been seen, in the long term the research suggests that the political, social and economic infrastructure of the country is weak and volatile and will be difficult to maintain and sustain as the country continues to grow in technology and awareness of the ruling party's political and economic actions. .

\section{The Short Term:}

Many scholars that I have addressed in this work, like Hilary Matfess, go over the ideas of benevolent autocracies and how governments like the RPF in Rwanda have created a domestic legitimacy that comes from their desire to restore peace and stability to the country. Much of this is done through a method noted by Matfess as the 'Carrot' and 'Stick.' When Kagame rose to power after the 1994 social rupture and took control of the presidency in 2000, his message was around unity and growth, which since then has molded and developed into the RPF government providing high levels of government services to the people as well as having a strong influence in the economy. Due to these services and government intervention, the 'carrots,' states like this earn the "developmental aspect of their moniker" (Matfess, 2015), and develop domestic support towards their cause. Of course, when a nation is developing, public support is crucial and having a government that works towards creating a thriving society around services provided by the 
government is, in many ways, seen as a good thing. However, on the other end of the 'carrot' is the 'stick' and this is where development can be stunted and has in many ways been stifled in the case of Rwanda. While perhaps on paper the 'rapid economic success' of the country has been applauded by western nations, the fact of the matter is the abuse and repressionary tactics that have been used in order to garner this have made us question throughout this work the legitimacy and sustainability of these measures, both politically and economically. Thus, this brings us to our point about the long term sustainable development of nations who approach development in the way that Rwanda has: high aid dependency, political and social rights abuses, and violent repression of those who offend RPF ideology.

\section{The Long Term:}

The 'stick' aspect of developmental authoritarianism is riddled with, as I have discussed throughout this work, repressive measures in order to maintain political dominance and control over the country. In the case of Rwanda, jailings, exiles, assassinations and indoctrination have all been tactics used to maintain RPF authority and a cult of personality around Kagame, both domestically and internationally, as the sort of 'savior' of Rwanda. While, of course, Kagame's leadership did ultimately bring the genocide to an end, it also ushered in an era of rising authoritarianism that has been widely ignored and indirectly supported by the international community. While the evidence does show that GDP growth has occurred in Rwanda since the genocide, it must be acknowledged that the amount of aid going into the country has also increased dramatically over the last three decades and its debt has increased to as much as $66 \%$, 
which begs the question of who is growing: the country's economic structures or the aid donations?

Rwanda, on paper, is a limited multiparty state, but in reality is truly under the control of the RPF and Kagame. With the economic development of this country not as great as hoped for, aid dependency becoming larger and larger parts of the way forward, and criticisms towards Kagame's leadership being outwardly repressed, what does the sustainability of this country's development look like? Furthermore, if Kagame is the only piece keeping this country together, what happens when his tyrannical rule comes to an end? Much of the political infrastructure is still dominated by the Tutsi elite, begging the question on whether cultural tensions could fuel over in the absence of the iron fisted leader?

As technology has developed and made its way into Rwanda, the ability of people to have their voices heard becomes harder and harder to repress. Repression still obviously occurs, but the consistent and violent actions taken against these people has pushed exiles and survivors to tell their stories, which are now slowly eroding away the legitimacy of Kagame's monolith of a vision. A benevolent autocracy can only work if the people they control believe the measures are benevolent. However, with the Rwandan economic miracle being proven wrong, a regime dependent on aid and repressive measures to maintain control of the population and infrastructure, and technology revealing the violent and difficult truths to the masses, the long term sustainability in Rwanda's development is truly questionable. Hilary Matfess, at the end of her work on Developmental Authoritarianism and Strongmen in Africa warrants that this type of leadership is durable, but eludes that these measures should be adhered to as transitions and not permanent, stating "promoting democracy and preventing the spread of authoritarianism therefore requires, at the least, a new approach to the typologies of authoritarian regimes: one 
that takes accounts of both the regimes ascent to power and its programmatic characteristics once in power" (Matfess, 2015).

\section{Sustainable Development: the necessity of democratic freedoms for economic and political success.}

There has been a scholarly discussion over the benefits of having a more authoritarian style of leadership when it comes to development. Historically, leaders like President Lee Kuan Yew of Singapore argued the restriction of civil liberties is ultimately good for the development of a nation and its growth. Even today, some scholars argue countries like China have had massive development due to the limitations of rights within their country. While the growth of these countries is impressive, the type of leadership and tools and geopolitical resources at their disposal are really not comparable when it comes to a small, landlocked country like Rwanda in the heart of Africa. Furthermore, when analyzing authoritarian development success the Lee Thesis is "based on very selective information, rather than on any general statistical testing over the wide-ranging data available" (Sen, 1998). However, it can't be denied that there seems to be a conclusion being drawn, arguing that democracy and the freedoms it entails isn't needed for a better life and, arguably, countries are buying into this claim. Even western leaders, like former

President Donald Trump, played with these notions in his speeches and admirations for autocrats like Vladimir Putin and Kim Jong-Un. The "strong man" approach has been reinforced in many ways, and nations supporting autocrats, like Kagame, only serve to push this narrative further. 
As our research comes to an end, I find the words of former Rwandan presidential candidate Umuhoza imperative: "current governance in Rwanda - that limits political space, lacks separation of power, impedes freedom of expression and represses critics of the government - cannot lead to sustainable development" (Umuhoza, 2021). And this research is important to consider from a Senian perspective, both economically and politically speaking. Many measurements of growth come from a place of economic foundations- measuring growth through numbers. But, from what our research has shown, those numbers do not account for the massive amount of aid brought into the country and how the growth is manipulated by the RPF governance; it does not measure how political freedoms are pushed aside, nor does it measure the validity of political governance in the country. I would ask the same question Sen proposes in his work Development as Freedom: "is this a sensible way of approaching the problems of economics needs and political freedoms- in terms of basic dichotomy that appears to undermine the relevance of political freedoms because the economic needs are so urgent?" (Sen, 1998). Rather, these needs are interconnected and our research has suggested that the eroding of political and civil freedoms in Rwanda have given way to a situation in which a tyrannical ruler, who may have started off with benevolent ideology, has delved into a corrupt political world where the economic gain is not what it actually seems. In even more recent publications, like Do Not Disturb, new information on the corruption of Kagame's political forces and tampering of economic indicators bring to light more indications that his autocratic rule is far from what the international community contends it to be.

In sustainable development, as long and arduous as a path as it is, incorporation of the people and their voices is essential. It is the responsibility of the people to pressure their representatives (voting, protesting and publicly criticizing) in order to maintain a government 
system that feels pressured to represent their people. In the case of Rwanda, those voices are ousted and have led to a very unstable system with a foundation of fear and indoctrination. This is not sustainable and it seems as though Rwandans, as their voices are able to be heard elsewhere (social media platforms) are starting to push for that change in their society. While this research contended, at first, that democracy may not be imperative to development, the interviews, statistical data accrued and investigation of how the Rwandan socio-political structures stand speaks for itself. I argue that the corrupt ways of developmental authoritarianism may bring about short term development, but in the end, should and must turn to a system that allows the people more involvement and interaction without fear of their government. Transitions of power are key and necessary for representation. It is time the era of Kagame comes to an end and a new era of political inclusivity, driven by the political freedoms necessary to achieve sustainable development, arises. 


\section{Appendix:}

ANNEXE 2 - INSTITUTIONS AU RWANDA

(Situation décembre 2020)

\section{PRÉSIDENCE ET GOUVERNEMENT ${ }^{1}$}

\begin{tabular}{|c|c|c|}
\hline Prénom et nom & Fonction & $\begin{array}{l}\text { adhésion politique, } \\
\text { ethnie, région d'origine }\end{array}$ \\
\hline Général Major Paul KAGAME & Président de la République & FPR, Tutsi, ex-réfugié \\
\hline $\begin{array}{l}\text { Judith UWIZEYE } \\
\text { Alphonsine MIREMBE }\end{array}$ & $\begin{array}{l}\text { Ministre à la Présidence } \\
\text { Secrétaire permanent }\end{array}$ & $\begin{array}{l}\text { NP, Hutu, Cyangugu } \\
\text { FPR, Tutsi, ex-réfugiée }\end{array}$ \\
\hline Edouard NGIRENTE & Premier Ministre & NP, Hutu, Kigali-Rural \\
\hline Evariste RUGIGANA & Directeur de Cabinet & FPR, Tutsi, ex-réfugié \\
\hline Inès MPAMBARA & $\begin{array}{l}\text { Ministre à la Primature chargée } \\
\text { des Affaires du Conseil des } \\
\text { Ministres }\end{array}$ & FPR, Tutsi, ex-réfugiée \\
\hline Doreen KAGARAMA & Secrétaire permanent & FPR, Tutsi, ex-réfugiée \\
\hline Jeannette BAYISENGE & $\begin{array}{l}\text { Ministre du Genre et de la } \\
\text { Promotion de la Famille }\end{array}$ & FPR, Hutu, Kigali-Ville. \\
\hline Assumpta INGABIRE & Secrétaire permanent & FPR, Tutsi, Butare \\
\hline Vincent BIRUTA & $\begin{array}{l}\text { Ministre des Affaires Etrangères } \\
\text { et de la Coopération } \\
\text { Internationale }\end{array}$ & PSD, Tutsi, Kigali-Ville \\
\hline Clémentine MUKEKA & Secrétaire permanent & FPR, Hutu, Gitarama \\
\hline Anastase SHYAKA & $\begin{array}{l}\text { Ministre de l'Administration } \\
\text { Locale }\end{array}$ & FPR, Hutu, Byumba \\
\hline Samuel DUSENGIYUMVA & Secrétaire permanent & FPR, Tutsi, Gitarama \\
\hline Johnston BUSINGYE & Ministre de la Justice & FPR, Tutsi, ex-réfugié \\
\hline Théophile MBONERA & Secrétaire permanent & FPR, Hutu, Ruhengeri \\
\hline Marie Solange KAYISIRE & $\begin{array}{l}\text { Ministre de la Gestion des } \\
\text { Urgences }\end{array}$ & FPR, Tutsi, ex-réfugiée \\
\hline Olivier KAYUMBA & Secrétaire permanent & FPR, Tutsi, ex-réfugié \\
\hline $\begin{array}{l}\text { Général Major Albert } \\
\text { MURASIRA }\end{array}$ & Ministre de la Défense & NP, Hutu?, Gisenyi \\
\hline $\begin{array}{l}\text { Lt-Colonel Innocent } \\
\text { GASHUGI }\end{array}$ & Secrétaire permanent & FPR, Tutsi, ex-réfugié \\
\hline Claver GATETE & Ministre des Infrastructures & FPR, Tutsi, ex-réfugié \\
\hline Patricia UWASE & Secrétaire permanent & FPR, Tutsi, ex-réfugiée \\
\hline
\end{tabular}

${ }^{1} \mathrm{NP}$ signifie sans affiliation politique officielle. Nous avons maintenu la référence aux anciennes préfectures en raison de l'absence de signification historique des actuelles provinces. 


\begin{tabular}{|c|c|c|}
\hline Claude MUSABYIMANA & $\begin{array}{l}\text { Ministre de l'Agriculture et de } \\
\text { l'Elevage } \\
\text { Secrétaire permanent }\end{array}$ & PSD, Hutu, Ruhengeri \\
\hline $\begin{array}{l}\text { Jeanne d'Arc } \\
\text { MUJAWAMARIYA }\end{array}$ & Ministre de l'Environnement & FPR, Hutu, Ruhengeri \\
\hline Patrick KARERA & Secrétaire permanent & FPR, Tutsi, ex-réfugié \\
\hline $\begin{array}{l}\text { Fanfan RWANYINDO } \\
\text { KAYIRANGWA }\end{array}$ & $\begin{array}{l}\text { Ministre de la Fonction } \\
\text { Publique et du Travail }\end{array}$ & NP, Tutsi, ex-réfugiée \\
\hline Gaspard MUSONERA & Secrétaire permanent & FPR, Tutsi, Kigali Rural \\
\hline Uzziel NDAGIJIMANA & $\begin{array}{l}\text { Ministre des Finances et de la } \\
\text { Planification Economique }\end{array}$ & FPR, Hutu, Gitarama \\
\hline Soraya HAKUZIYAREMYE & $\begin{array}{l}\text { Ministre du Commerce, de } \\
\text { l'Industrie }\end{array}$ & NP, Hutu, Gitarama \\
\hline Michel SEBERA & Secrétaire permanent & FPR, Tutsi, ex-réfugié \\
\hline Valentine UWAMARIYA & Ministre de l'Education & FPR, Hutu, Cyangugu \\
\hline Samuel MULINDWA & Secrétaire permanent & FPR, Tutsi, ex-réfugié \\
\hline $\begin{array}{l}\text { Aurore Mimosa } \\
\text { MUNYANGAJU }\end{array}$ & Ministre des Sports & FPR, Tutsi, ex-réfugiée \\
\hline Didier SHEMA MABOKO & Secrétaire permanent & FPR, Hutu, Kigali-Ville \\
\hline Daniel NGAMIJE & Ministre de la Santé & FPR, Tutsi, ex-réfugié \\
\hline Zacharie IYAMUREMYE & Secrétaire permanent & \\
\hline Paula INGABIRE & $\begin{array}{l}\text { Ministre des Technologies de } \\
\text { l'Information, de la } \\
\text { Communication et de } \\
\text { l'Innovation }\end{array}$ & FPR, Tutsi, ex-réfugiée \\
\hline Yves IRADUKUNDA & Secrétaire permanent & FPR, Hutu, Gitarama \\
\hline Rosemary MBABAZI & $\begin{array}{l}\text { Ministre de la Jeunesse et de la } \\
\text { Culture }\end{array}$ & FPR, Tutsi, ex-réfugiée \\
\hline Emmanuel BIGENIMANA & Secrétaire permanent & FPR, Hutu, Gisenyi \\
\hline Ignacienne NYIRARUKUNDO & $\begin{array}{l}\text { Secrétaire d'État au ministère de } \\
\text { l'Administration locale chargé } \\
\text { des affaires sociales }\end{array}$ & PL, Tutsi, Gikongoro \\
\hline Solina NYIRAHABIMANA & $\begin{array}{l}\text { Secrétaire d'Etat au ministère de } \\
\text { la Justice chargé de la } \\
\text { Constitution et des autres lois }\end{array}$ & FPR, Hutu, Gitarama \\
\hline Gaspard TWAGIRAYEZU & $\begin{array}{l}\text { Secrétaire d'État au ministère de } \\
\text { l'Éducation chargé des écoles } \\
\text { primaires et secondaires }\end{array}$ & \\
\hline Claudette IRERE & $\begin{array}{l}\text { Secrétaire d'État au ministère de } \\
\text { l'Éducation chargé de la } \\
\text { Technologie et de } \\
\text { l'Enseignement Technique et } \\
\text { Professionnel. }\end{array}$ & FPR, Tutsi, ex-réfugiée \\
\hline
\end{tabular}




\begin{tabular}{|l|l|l|}
\hline Edouard BAMPORIKI & $\begin{array}{l}\text { Secrétaire d'Etat chargé de la } \\
\text { Jeunesse et de la culture }\end{array}$ & FPR, Hutu, Cyangugu \\
\hline $\begin{array}{l}\text { Lt Colonel MPUNGA } \\
\text { Tharcisse }\end{array}$ & $\begin{array}{l}\text { Secrétaire d'Etat au Ministère } \\
\text { de la Santé chargé de la santé } \\
\text { publique et des soins de santé } \\
\text { primaires. }\end{array}$ & FPR, Tutsi, ex-refugié \\
\hline Claudine UWERA & $\begin{array}{l}\text { Secrétaire d'Etat au ministère } \\
\text { des Finances et de la } \\
\text { Planification économique } \\
\text { chargée de la planification } \\
\text { économique. }\end{array}$ & FPR, Tutsi, ex-réfugiée \\
\hline Richard TUSHABE & $\begin{array}{l}\text { Secrétaire d'Etat au ministère } \\
\text { des Finances et de la } \\
\text { Planification économique } \\
\text { chargé des Finances Publiques }\end{array}$ & FPR, Tutsi, ex-réfugié \\
\hline Manassé NSHUTI & $\begin{array}{l}\text { Secrétaire d'Etat au ministère } \\
\text { des Affaires Etrangères, chargé } \\
\text { de la Communauté de l'Afrique } \\
\text { de l'Est. }\end{array}$ & FPR, Tutsi, ex-réfugié \\
\hline $\begin{array}{l}\text { Jean Chrysostome } \\
\text { NGABITSINZE }\end{array}$ & $\begin{array}{l}\text { Secrétaire d'Etat au ministère de } \\
\text { l'Agriculture et de l'Elevage }\end{array}$ & PSD, Hutu, Gikongoro \\
\hline Clare AKAMANZI & CEO of RDB & FPR, Tutsi, ex-réfugiée \\
\hline Francis GATARE & $\begin{array}{l}\text { CEO of Rwanda Mines, } \\
\text { Petroleum and Gas Board }\end{array}$ & FPR, Tutsi, ex-refugié \\
\hline
\end{tabular}

\section{GOUVERNEURS}

\begin{tabular}{|l|l|l|}
\hline Province & prénom et nom & $\begin{array}{l}\text { adhésion politique, ethnie, } \\
\text { région d'origine }\end{array}$ \\
\hline Province de l'Est & Fred MUFURUKYE & FPR, Tutsi, ex-réfugié \\
\hline Province du Nord & $\begin{array}{l}\text { Jean Marie Vianney } \\
\text { GATABAZI }\end{array}$ & FPR, Hutu, Byumba \\
\hline Province de l'Ouest & Alphonse MUNYENTWARI & FPR, Tutsi, Butare \\
\hline Province du Sud & Alice KAYITESI & FPR, Tutsi, Gitarama \\
\hline Mairie de Kigali & Pudence RUBINGISA & FPR, Tutsi, ex-réfugié \\
\hline
\end{tabular}

\section{APPAREIL JUDICIAIRE}

\begin{tabular}{|l|l|l|}
\hline cour / tribunal & nom du président & ethnie et région d'origine \\
\hline $\begin{array}{l}\text { Cour Suprême (Président) } \\
\begin{array}{l}\text { Cour Suprême } \\
\text { (Vice-présidente) }\end{array}\end{array}$ & Faustin NTEZIRYAYO & Hutu, Gitarama \\
\hline Cour d'Appel & $\begin{array}{l}\text { Aimé KALIMUND Thérèse MUKAMULISA } \\
\text { MUYOBOKE }\end{array}$ & Tutsi, Kigali-Ville \\
\hline Haute Cour & Xavier NDAHAYO & Tutsi, ex-réfugié \\
\hline
\end{tabular}




\begin{tabular}{|l|l|l|}
\hline $\begin{array}{l}\text { Procureur Général de la } \\
\text { République }\end{array}$ & Aimable HAVUGIYAREMYE & Tutsi, ex-réfugié \\
\hline $\begin{array}{l}\text { Rwanda Investigation } \\
\text { Bureau (RIB) }\end{array}$ & Colonel Jeannot RUHUNGA & FPR, Tutsi, ex-réfugié \\
\hline
\end{tabular}

\section{FORCES RWANDAISES DE DÉFENSE (FRD)}

\begin{tabular}{|l|l|l|}
\hline Institution & prénom et nom & $\begin{array}{l}\text { adhésion politique, ethnie, } \\
\text { région d'origine }\end{array}$ \\
\hline Commandant en chef & Général-Major Paul KAGAME & FPR, Tutsi, ex-réfugié \\
\hline Chef d'État-major général & Général Jean Bosco KAZURA & FPR, Tutsi, ex-réfugié \\
\hline $\begin{array}{l}\text { Chef d'État-major de } \\
\text { l'armée de terre }\end{array}$ & $\begin{array}{l}\text { Lieutenant-Général Jean Jacques } \\
\text { MUPENZI }\end{array}$ & FPR, Tutsi, ex-réfugié \\
\hline $\begin{array}{l}\text { Chef d'État-major de } \\
\text { l'armée de l'air }\end{array}$ & $\begin{array}{l}\text { Général-Major Emmanuel } \\
\text { BAYINGANA }\end{array}$ & FPR, Tutsi, ex-réfugié \\
\hline $\begin{array}{l}\text { Chef d'Etat-major de } \\
\text { l'armée de réserve }\end{array}$ & General Fred IBINGIRA & FPR, Tutsi, ex-réfugié \\
\hline
\end{tabular}

\section{CORPS DIPLOMATIQUE}

\begin{tabular}{|l|l|l|}
\hline lieu d'accréditation & prénom et nom & $\begin{array}{l}\text { adhésion politique, ethnie, } \\
\text { région d'origine }\end{array}$ \\
\hline Abuja & Stanislas KAMANZI & PSD, Hutu, Byumba \\
\hline Abu Dhabi & Emmanuel HATEGEKA & FPR, Tutsi, Butare \\
\hline Addis-Abeba & Hope TUMUKUNDE & FPR, Tutsi, ex-réfugié \\
\hline Accra & Aissa KIRABO KACYIRA & FPR, Tutsi, ex-réfugiée \\
\hline Ankara & Fidelis MIRONKO & FPR, Tutsi, ex-réfugié \\
\hline Berlin & César IGOR & FPR, Tutsi, ex-réfugié \\
\hline Brazzaville & Théoneste MUTSINDASHYAKA & FPR, Tutsi, Kigali-Ville \\
\hline Bruxelles & Dieudonné SEBASHONGORE & FPR, Tutsi, ex-réfugié \\
\hline Bujumbura & Vacant & \\
\hline Dakar & Jean-Pierre KARABARANGA & FPR, Tutsi, Butare \\
\hline Dar es Salam & Général-Major Charles KARAMBA & FPR, Tutsi, ex-réfugié \\
\hline Genève & Marie Chantal RWAKAZINA & FPR, Tutsi, ex-réfugiée \\
\hline Harare & James MUSONI & FPR, Tutsi, ex-réfugié \\
\hline Kampala & Colonel Joseph RUTABANA & FPR, Tutsi, ex-réfugié \\
\hline Khartoum & Colonel MUNYANEZA MUZUNGU & FPR, Tutsi, ex-réfugié \\
\hline Kinshasa & Vincent KAREGA & FPR, Tutsi, ex-réfugié \\
\hline
\end{tabular}




\begin{tabular}{|l|l|l|}
\hline La Haye & Olivier NDUHUNGIREHE & PSD, Hutu, Butare \\
\hline Le Caire & Alfred KALISA & FPR, Tutsi, ex-réfugié \\
\hline Londres & Yamina KARITANYI & FPR, Tutsi, ex-réfugiée \\
\hline Luanda & Wellars GASAMAGERA & FPR, Tutsi, Gitarama \\
\hline Lusaka & Amandin RUGIRA & FPR, Hutu, Cyangugu \\
\hline Maputo & Claude NIKOBISANZWE & FPR, Tutsi, ex-réfugié \\
\hline Moscou & $\begin{array}{l}\text { Lieutenant Général MUSHYO } \\
\text { KAMANZI }\end{array}$ & FPR, Tutsi, ex-réfugié \\
\hline Nairobi & Richard MASOZERA & FPR, Tutsi, ex-réfugié \\
\hline New Delhi & Jacqueline MUKANGIRA & FPR, Tutsi, ex-réfugiée \\
\hline New York & Valentine RUGWABIZA & FPR, Tutsi, ex-réfugiée \\
\hline Ottawa & Prosper HIGIRO & PL, Tutsi, Kibungo \\
\hline Paris & François Xavier NGARAMBE & FPR, Tutsi, Gitarama \\
\hline Pékin & James KIMONYO & PSD, Tutsi, ex-réfugié \\
\hline Pretoria & Eugene SEGORE KAYIHURA & FPR, Tutsi, ex-réfugié \\
\hline Qatar & François NKULIKIYIMFURA & FPR, Tutsi, ex-réfugié \\
\hline Rabat & Zaina NYIRAMATAMA & PDI, Hutu, Gitarama \\
\hline Seoul & Yasmin AMRI SUED & FPR, Hutu, Ruhengeri \\
\hline Singapour & Jean de Dieu UWIHANGANYE & NP, Tutsi, Byumba \\
\hline Stockholm & Christine NKURIKIYINKA & FPR, Hutu, Gitarama \\
\hline Tel-Aviv & Vacant & \\
\hline Tokyo & Ernest RWAMUCYO & FPR, Tutsi, ex-réfugié \\
\hline Washington & Mathilde MUKANTABANA & FPR, Tutsi, ex-réfugiée \\
\hline Note: Appendx in & Reyntjens, Fr (202O). RWANDA, PO & itical Chronicles of the Great \\
\hline
\end{tabular}

Note: Appendix in Reyntjens, F. (2020). RWANDA. Political Chronicles of the Great Lakes

Region. file://Users/manuelgrajeda/Downloads/Political\%20chronicle\%20Rwanda\%202019.pdf 


\section{References}

Anonymous. (1997). A/RES/51/240 - E - A/RES/51/240 -Desktop. UNdocs.Org. https://undocs.org/en/A/RES/51/240

Bardhan, P. (1999). Democracy's Values. Cambridge University Press.

BTI 2020. (2020). BTI-Project.

https://www.google.com/url?q=https://www.bti-project.org/en/reports/country-report-RW A-2020.html\&sa $=$ D\&source $=$ docs\&ust $=1634188970106000 \&$ usg=AOvVaw3T15UB0So dD7OVwg6NfcAV

Carroll, R. (2004). US chose to ignore Rwandan genocide. The Guardian. https://www.theguardian.com/world/2004/mar/31/usa.rwanda

Cascais, A. (2020). 20 years under Rwanda's “benevolent dictator" Paul Kagame. DW. https://www.google.com/url?q=https://www.dw.com/en/20-years-under-rwandas-benevol ent-dictator-paul-kagame/a-53159121\&sa $=\mathrm{D} \&$ source $=$ docs\&ust $=1634188970159000 \& u$ s $\mathrm{g}=\mathrm{AOvVaw} 3 \mathrm{Pg} 2 \mathrm{NrFzQBk} 2 \mathrm{AN} 21 \mathrm{R} \operatorname{lnHLN}$

Chakravarty, A. (2015). Investing in Authoritarian Rule. Cambridge Core.

Council on Foreign Relations: a Conversation With President Kagame | New York, 19 September 2017. (2017, September 19). [Video]. YouTube.

https://www.youtube.com/watch?v=qKtlcg_d8go\&t=296s

Easterly, W. (2011). Benevolent Autocrats. NYU, NBER, BREAD. Published.

Economic growth in Rwanda has arguably come at the cost of democratic freedom. (2019). World Finance. 
https://www.worldfinance.com/markets/economic-growth-in-rwanda-has-arguably-comeat-the-cost-of-democratic-freedom

Emas, R. (2015). Brief for GSDR 2015 The Concept of Sustainable Development: Definition and Defining Principles. The United Nations.

https://sustainabledevelopment.un.org/content/documents/5839GSDR\%202015_SD_conc ept_definiton_rev.pdf

Germain, N.(2019). The Financial Times says Rwanda has manipulated its economic data. The Financial Times.

https://www.france24.com/en/20190813-financial-times-says-rwanda-has-manipulated-its -economic-data

Gilson, R. J., \& Milhaupt, C. J. M. (2011). Economically Benevolent Dictators: Lessons for Developing Democracies. The American Journal of Comparative Law. Published. https://academic.oup.com/ajcl/article-abstract/59/1/227/2571321

Giridharadas, A. (2018). The Clinton Doctrine: Prophecies and failures. Observer Research Foundation. https://www.orfonline.org/expert-speak/the-clinton-doctrine-prophecies-failures/

Guriev, S., \& Treisman, D. T. (2020). A Theory of Informational Autocracy. Squarespace.Com. https://static1.squarespace.com/static/5a4d2512a803bb1a5d9aca35/t/5e67165beddd0f57b b8395bb/1583814237621/Guriev+Treisman+February+2020.pdf

Kagame: Democracy is not defined by the West. (2021, February 17). [Video]. YouTube. https://www.youtube.com/watch?v=-kBdZSjSwjg

Keffler, N.(2019). Economic growth in Rwanda has arguably come at the cost of democratic freedom. World Finance: The Voice of the Market. 
https://www.worldfinance.com/markets/economic-growth-in-rwanda-has-arguably-comeat-the-cost-of-democratic-freedom

Louis, M. (2020, December 16). IMF Executive Board Completes Third Review Under the Policy Coordination Instrument (PCI) for Rwanda. IMF.

https://www.imf.org/en/News/Articles/2020/12/16/pr20376-rwanda-imf-executive-boardcompletes-third-review-under-the-pci

Mailafia, O. (2017, August 28). Paul Kagame as a Lenin and a Tsar. Vanguard News. https://www.vanguardngr.com/2017/08/paul-kagame-lenin-tsar/

Mamdani, M. (2002). When Victims Become Killers: Colonialism, Nativism, and the Genocide in Rwanda. Princeton University Press.

Many Africans see Kagame's Rwanda as a model. They are wrong. (2017). The Economist. https://www.economist.com/leaders/2017/07/15/many-africans-see-kagames-rwanda-as-a -model-they-are-wrong

Matfess, H. (2015). Rwanda and Ethiopia: Developmental Authoritarianism and the New Politics of African Strong Men. JSTOR. Published.

Mattes, M., \& Rodriguez, M. (2014). Autocracies and International Cooperation. JSTOR. Published. https://www.jstor.org/stable/24014613

Mgbako, C. A. (2005). Ingando Solidarity Camps: Reconciliation and Political Indoctrination in Post-Genocide Rwanda Note. FLASH: The Fordham Law Archive of Scholarship and History. Published.

https://ir.lawnet.fordham.edu/cgi/viewcontent.cgi?article=1376\&context=faculty_scholar ship 
Mudge, L. (2020). What Press Freedom Looks like in Rwanda. Human Rights Watch. https://www.hrw.org/node/378636/printable/print

Olsen, N. (2019). The Sovereign Consumer A New Intellectual History of Neoliberalism. Palgrave Macmillan.

Overview. (2021). World Bank. https://www.worldbank.org/en/country/rwanda/overview\#1 Purdeková, A. (2011a). Even If I Am Not Here, There Are So Many Eyes”: Surveillance and State Reach in Rwanda. Journal of Modern African Studies. Published. https://www.researchgate.net/publication/231769690_Even_If_I_Am_Not_Here_There_ Are_So_Many_Eyes_Surveillance_and_State_Reach_in_Rwanda

Purdeková, A. (2011b). Rwanda's Ingando camps: liminality and the reproduction of power. University of Oxford. https://www.rsc.ox.ac.uk/publications/rwanda2019s-ingando-camps-liminality-and-the-re production-of-power

Reyntjens, F. (2004). Rwanda, Ten Years On: From Genocide to Dictatorship. African Affairs. Published.

Reyntjens, F. (2020). RWANDA. Political Chronicles of the Great Lakes Region. file://Users/manuelgrajeda/Downloads/Political\%20chronicle\%20Rwanda\%202019.pdf Robinson, N. J. (2016). BILL CLINTON'S SHAMEFUL GENOCIDE DENIAL. Current Affairs. https://www.currentaffairs.org/2016/05/bill-clintons-shameful-genocide-denial

Roth, K. (2009). Response to The New Times Article on Rwandan Genocide. Human Rights Watch. https://www.hrw.org/news/2009/05/18/response-new-times-article-rwandan-genocide\# Rwanda. (2016). Sahistory.Org. https://www.sahistory.org.za/place/rwanda 
Rwanda: Disappearances Require Credible Investigations. (2020, October 28). Human Rights Watch.

https://www.hrw.org/news/2019/08/15/rwanda-disappearances-require-credible-investigat ions

Rwanda: Information on ingando camps, including organization, structure, programs and participation; instances of human rights violations in the camps (2010-November 2014).

(2014). Refworld. https://www.refworld.org/docid/56136dfa4.html

The Rwandan miracle. (2019, May 7). UNESCO.

https://en.unesco.org/courier/2019-2/rwandan-miracle

The Rwandan Patriotic Front's business empire. (2017, March 2). The Economist.

https://www.economist.com/business/2017/03/02/the-rwandan-patriotic-fronts-business-e mpire

Seay, L. (2017). Rwanda's gacaca courts are hailed as a post-genocide success. The reality is more complicated. The Washington Post. https://www.washingtonpost.com/news/monkey-cage/wp/2017/06/02/59162/

Sen, A. (2000). Development as Freedom (Reprint ed.). Anchor.

Skok, S. (2020). What Impact Did the Belgian Presence in Rwanda Have to Spark Further Conflict? Education.Seattlepi.Com. https://education.seattlepi.com/impact-did-belgian-presence-rwanda-spark-further-conflic t-5558.html

Sundaram, A. (2014). Rwanda: The Darling Tyant. Politico Magazine. https://www.politico.com/magazine/story/2014/02/rwanda-paul-kagame-americas-darling -tyrant-103963/ 
Taiwo, K. B. (2018, September 16). The Rwandan miracle: How a nation devastated by genocide has risen to become one of the fastest growing economies in Africa. Medium. https://medium.com/@kwabena.taiwo/the-rwandan-miracle-how-a-nation-devastated-bygenocide-has-risen-to-become-one-of-the-fastest-1182b3ac535d

The World Bank. (2019). Rwanda Systematic Country Diagnostic.

https://documents1.worldbank.org/curated/en/219651563298568286/pdf/Rwanda-System atic-Country-Diagnostic.pdf

Umuhoza, V. (2021). My story proves Rwanda's lack of respect for good governance and human rights. The Guardian.

https://www.theguardian.com/global-development/commentisfree/2021/jun/01/my-storyproves-rwandas-lack-of-respect-for-good-governance-and-human-rights

Wenders, J. T. W. (1990). Freedom and Democracy Are Different. Fee.Org. https://fee.org/articles/freedom-and-democracy-are-different/

The World Bank in Rwanda. (2021). The World Bank.

https://www.worldbank.org/en/country/rwanda/overview\#: :text=Rwanda\%20now\%20as pires $\% 20$ to\%20Middle,achieving\%20the\%20Sustainable\%20Development\%20Goals. 